CHARAKTERYSTYKA RUCHU TURYSTYCZNEGO W WYBRANYCH SKANSENACH W POLSCE LA CARACTÉRISTIQUE DU MOUVEMENT TOURISTIQUE DANS LES MUSÉES ETHNOGRAPHIQUES EN PLEIN AIR EN POLOGNE

\author{
A DESCRIPTION OF THE TOURIST TRAFFIC IN SELECTED \\ ETHNOGRAPHICAL MUSEUMS IN POLAND
}

\begin{abstract}
W artykule zaprezentowano krótką charakterystykę ruchu turystycznego w wybranych polskich skansenach. Analiza porównawcza dotyczy takich cech ruchu turystycznego, jak: wielkość, struktura i sezonowość frekwencji, a także zasięg przestrzennego oddzialywania poszczególnych placówek.
\end{abstract}

\title{
1. WPROWADZENIE
}

Artykuł stanowi podsumowanie części dwuletnich badań ankietowych prowadzonych przez autora w latach 1996-1997 w sześciu muzeach skansenowskich w Polsce. Były to placówki w: Chorzowie, Klukach, Lednogórze (Dziekanowicach), Nowogrodzie Łomżyńskim, Sanoku i Tokarni. Główną ideą przyświecającą takiemu doborowi muzeów było ukazanie ich dużej różnorodności zarówno pod względem powierzchni, wieku, liczby zgromadzonych obiektów, położenia (na wsi, w mieście, w różnych strefach krajobrazowych), jak i wynikającej z tego wielkości i charakteru ruchu turystycznego.

Ogółem badaniami ankietowymi objętych zostało blisko 1,5 tys. widzów muzealnych (tab. I). Ankietowani byli wyłącznie zwiedzający powyżej 18 roku życia (mniej więcej co dziesiąta osoba wychodząca ze skansenu), przy czym odpowiedzi z reguły dotyczyły całej rodziny, grupy zwiedzających (faktycznie badaniami objęto więc trzy-czterokrotnie więcej osób). Ankieta zawierała kilkanaś- 
cie pytań, $m$. in. o motywy i charakter wizyty w skansenie, źródło informacji o muzeum, środek lokomocji, ocenę ekspozycji.

Analizy turystów zwiedzających skansen w grupach zorganizowanych dokonano na podstawie rachunków za bilety wstępu lub rejestrów wycieczek prowadzonych przez pracowników muzeum (liczba grup, miejsca pochodzenia, organizator wycieczki, liczba uczestników itp.).

Tabela I

Badania ruchu turystycznego w wybranych skansenach w latach 1996-1997

Les recherches sur le mouvement touristique dans les musées ethnogaphiques choisis dans les années 1996-1997

\begin{tabular}{|c|c|c|c|}
\hline \multirow[b]{2}{*}{ Nazwa skansenu } & \multirow[b]{2}{*}{ Termin badań } & \multicolumn{2}{|c|}{ Liczba ankiet } \\
\hline & & $\begin{array}{c}\text { turyści } \\
\text { indywidualni }\end{array}$ & $\begin{array}{l}\text { grupy zor- } \\
\text { ganizowane }\end{array}$ \\
\hline $\begin{array}{l}\text { Muzeum Wsi Stowińskiej } \\
\text { w Klukach }\end{array}$ & $31.07 .-10.08 .1996$ & 240 & $942^{*}$ \\
\hline $\begin{array}{l}\text { Górnośląski Park Etnograficzny } \\
\text { w Chorzowie }\end{array}$ & $\begin{array}{c}15-16.06 .1996 \\
30.08 .-21.09 .1996 \\
\end{array}$ & 216 & 75 \\
\hline $\begin{array}{l}\text { Wielkopolski Park Etnograficzny } \\
\text { w Lednogórze }\end{array}$ & $3-10.07 .1997$ & 314 & 72 \\
\hline $\begin{array}{l}\text { Muzeum Wsi Kieleckiej Park Etnograficzny } \\
\text { w Tokarni }\end{array}$ & $\begin{array}{l}18-25.07 .1997 \\
27-29.08 .1997 \\
\end{array}$ & 203 & $510^{*}$ \\
\hline $\begin{array}{l}\text { Skansen Kurpiowski w Nowogrodzie } \\
\text { Łomzyńskim }\end{array}$ & $31.07 .-10.08 .1997$ & 182 & $336^{*}$ \\
\hline $\begin{array}{l}\text { Muzeum Budownictwa Ludowego } \\
\text { w Sanoku }\end{array}$ & $14-22.08 .1997$ & 321 & $1211 *$ \\
\hline Razem & $x$ & 1476 & $\mathrm{x}$ \\
\hline
\end{tabular}

* Liczba grup scharakteryzowanych na podstawie rachunków za bilety wstępu.

\section{WIELKOŚĆ FREKWENCJI}

W miarę zanikania tradycyjnej kultury ludowej wzrasta zainteresowanie muzeami skansenowskimi. Zgromadzone w nich zabytki drewnianej architektury, narzędzia i przedmioty codziennego użytku, wyroby rzemieślnicze i dzieła wiejskich artystów przyciągają coraz szersze rzesze zwiedzających.

Niezwykła popularność skansenów obserwowana jest od wielu lat w wysoko rozwiniętych krajach Europy Zachodniej. W wielu placówkach frekwencja nierzadko sięga 300-400 tys. osób rocznie (S p i s s 1985).

Liczba zwiedzających polskie muzea na wolnym powietrzu jest znacznie skromniejsza - nie przekracza 100 tys. Porównanie frekwencji pod koniec lat 
siedemdziesiątych i na początku dziewięćdziesiątych (rys. 1) dowodzi, iż czołówka najczęściej odwiedzanych muzeów właściwie nie zmienia się. Tworzą ja te same starsze placówki, prowadzące od lat szeroką działalność oświatową i kulturalną ${ }^{1}$ : Muzeum Budownictwa Ludowego w Olsztynku (średnia frekwencja w latach 1992-1994 - 73,3 tys.), Muzeum Budownictwa Ludowego w Sanoku (60,6 tys.), Nadwiślański Park Etnograficzny w Wygiełzowie (54,5 tys.) oraz Muzeum Wsi Opolskiej w Opolu (51,8 tys.). W pozostałych placówkach frekwencja najczęściej wahała się pomiędzy 20 a 40 tys. Trzeba jednak pamiętać, że był to najtrudniejszy okres dla muzealnictwa, zaznaczający się 30-50\% spadkiem frekwencji. Załamanie ruchu turystycznego miało jednak różny cha-

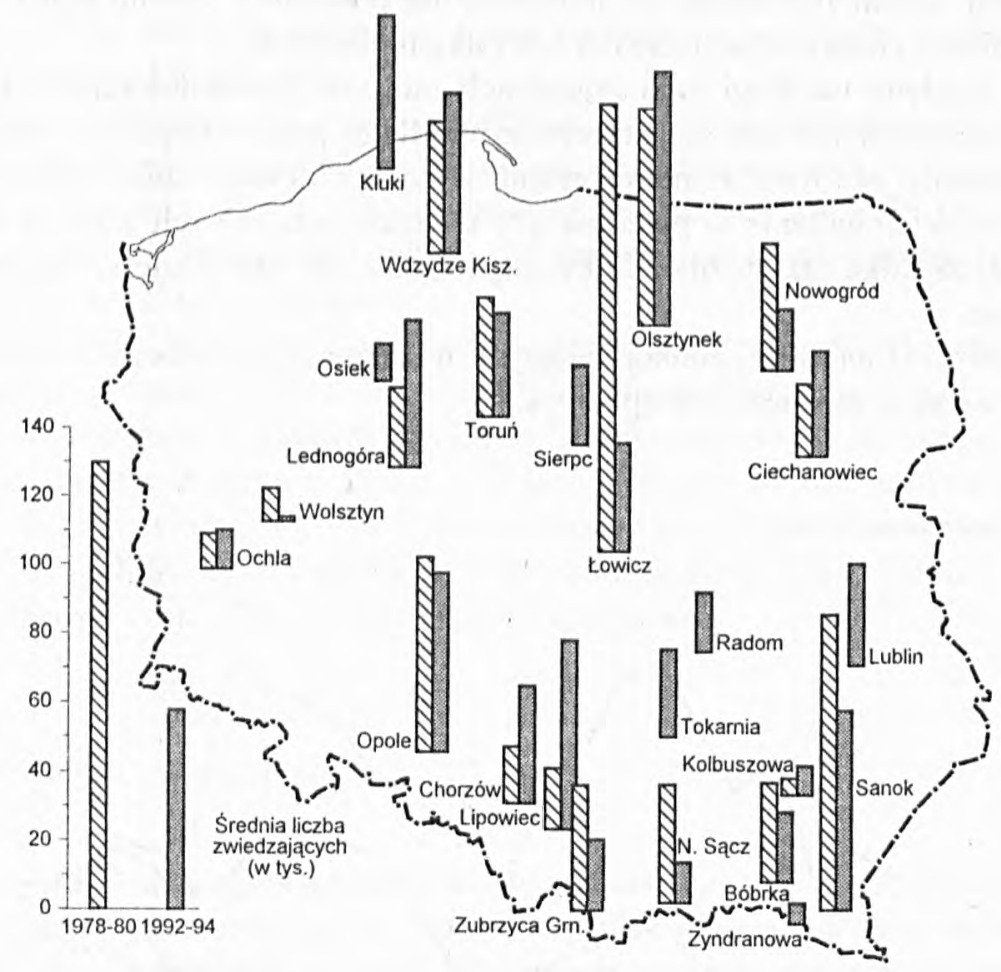

Rys. 1. Średnia liczba zwiedzających skanseny w Polsce w latach 1978-1980 i 1992-1994 (opracowanie własne za J. C z a j k ow s k i m (1981) i na podstawie ankiet)

Dessin 1. Le nombre moyen de visiteurs des musées ethnographiques en Pologne dans les années 1978-1980 et 1992-1994

(élaboration propre d'aprés J. Czajkowski (1981) et à la base des enquêtes)

${ }^{1}$ Podana przez J. C z a j k o w s k i e g o (1981) frekwencja w skansenie w Lowiczu (w roku 1980 aż 147 tys.!) budzi duże watpliwości i prawdopodobnie odnosi się do całego muzeum, a nie przymuzealnej ekspozycji skansenowskiej. 
rakter i czas trwania. Część muzeów (zwłaszcza te położone w dużych miastach i atrakcyjnych miejscowościach turystycznych) dość szybko „odnalazła się" w nowej rzeczywistości. Znaczący wzrost odnotowano zwłaszcza w Chorzowie, Wygiełzowie, Lednogórze - Dziekanowicach, Wdzydzach Kiszewskich i Klukach, oraz młodych muzeach otwartych dla zwiedzających w latach osiemdziesiątych (np. w Radomiu, Sierpcu, Tokarni). Niektórym muzeom nie udało się jednak jeszcze osiagnąć poziomu frekwencji sprzed $1990 \mathrm{r}$.

Liczba zwiedzających w wybranych do szczegółowej analizy skansenach wahała się w $1997 \mathrm{r}$. od 35 tys. (Nowogród, Tokarnia) do prawie 75 tys. (Sanok). Niepełne lub mało wiarygodne dane archiwalne (zwłaszcza dla MWS w Klukach i KPE w Nowogrodzie Łomżyńskim) nie pozwalają na dokładne odtworzenie zmian frekwencji od momentu ich powstania. Pewne jednak trendy i zjawiska są charakterystyczne dla wszystkich placówek.

Ze względu na długi czas organizacji muzeów skansenowskich większość $\mathrm{z}$ nich udostępniana jest do zwiedzania na długo przed oficjalnym otwarciem. Od momentu otwarcia zainteresowanie nowym obiektem stale rośnie, co ma swoje odzwierciedlenie $w$ gwałtownym wzroście muzealnych widzów w ciągu pierwszych kilku lat. Później frekwencja spada lub stabilizuje się na pewnym poziomie.

W historii najdłıżej funkcjonujących muzeów skansenowskich można wyróżnić wyraźne pięć okresów (por. rys. 2):

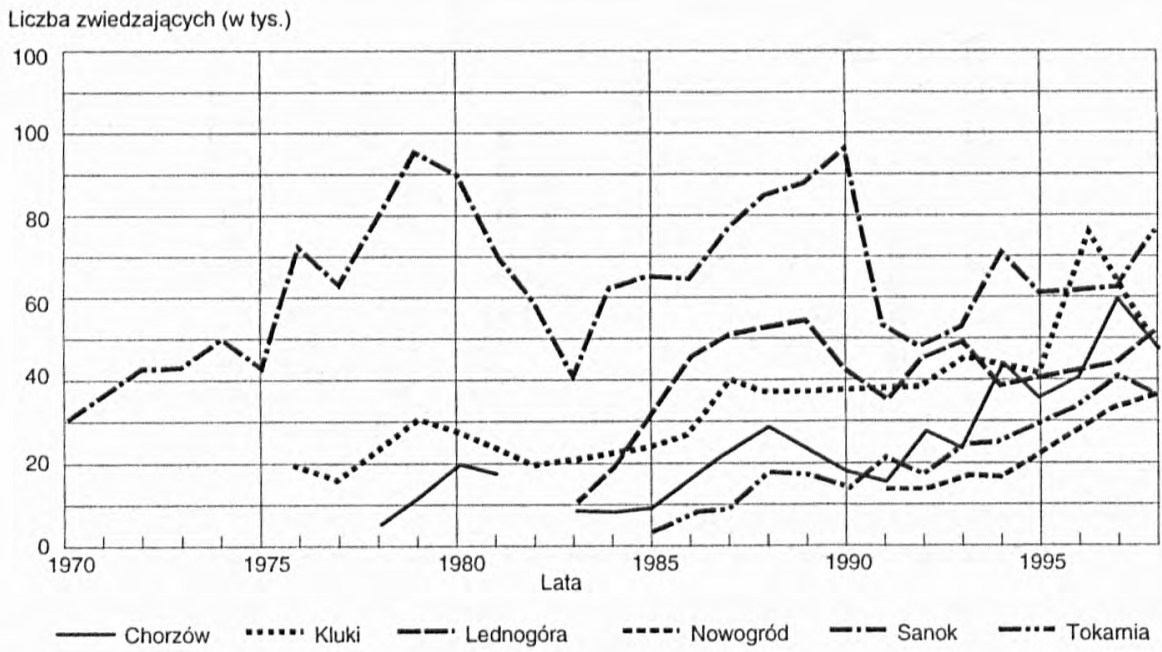

Rys. 2. Frekwencja w wybranych skansenach w Polsce (opracowanie własne na podstawie informacji dyrekcji muzeów)

Dessin 2. La fréquence dans les musées ethnographiques choisis en Pologne (élaboration propre à la base des informations fournies par la direction des musées) 
- lata siedemdziesiąte, charakteryzujące się stałym systematycznym wzrostem liczby zwiedzających, o dynamice przyrostu liczby publiczności muzealnej świadczy przykład najczęściej odwiedzanego MBL w Sanoku, gdzie w ciągu kilku lat frekwencja podwoiła się, osiągając w 1978 r. 95 tys. widzów;

- lata 1980-1982, które przyniosły drastyczny spadek liczby zwiedzajacych, wynikający z ogólnej sytuacji społeczno-politycznej kraju (kryzys gospodarczy, stan wojenny), w Klukach i Sanoku wyniósł on ok. $40 \%$, a w Chorzowie niemal $60 \%$;

- lata 1983-1989 to kolejny czas wzrostu, MBL w Sanoku osiagnęło w roku 1989 po raz drugi 95 tys. widzów, maksymalną frekwencję w swej historii odnotował także Wielkopolski Park Etnograficzny w Lednogórze-Dziekanowicach (ponad 53,5 tys. gości w 1988 r.), do skansenu w Klukach regularnie przybywało po 40 tys. turystów rocznie, a widownia muzeum w Tokarni z roku na rok zwiększała się o kilka tysięcy;

- lata 1990-1992, w których nastapiło ponowne załamanie frekwencji, w czterech badanych placówkach odnotowano wyraźny spadek liczby zwiedzających: w Tokarni o 17,4\%, Chorzowie o $33,5 \%$, Lednogórze o $35,1 \%$, a w Sanoku aż o $50,5 \%$, jedynie w Klukach był praktycznie niezauważalny (niewiele ponad $8 \%$ ) i trwal tylko jeden rok;

- lata 1993-1997 to okres stałego, systematycznego odbudowywania poziomu frekwencji sprzed 1990 r., we wszystkich muzeach wyraźnie zaznaczyła się tendencja wzrostowa, rekordy frekwencji odnotowano w Klukach (ponad 70 tys.), Chorzowie (prawie 59 tys.), Tokarni (40 tys.) i Nowogrodzie (36 tys., choć w rzeczywistości turystów było znacznie więcej, gdyż skansen bez wchodzenia do obiektów można zwiedzać bezpłatnie), jedynie w Sanoku liczba zwiedzających była o ok. $20 \%$ niższa niż przed kryzysem.

\section{STRUKTURA FREKWENCJI}

Muzea skansenowskie są specyficznymi muzeami pod względem struktury zwiedzających. Do niedawna w niemal wszystkich placówkach tego typu zdecydowanie dominowali zwiedzający w grupach zorganizowanych, a zwłaszcza młodzież w ramach wycieczek szkolnych. W latach 1984-1988 grupy szkolne stanowily przeciętnie od $40 \%$ (Chorzów) do ponad $70 \%$ (Tokarnia) ogółu turystów. Istotny odsetek tworzyli także uczestnicy innych niż szkolne grup (głównie tzw. wycieczek zakładowych). Średni udział tego typu widzów wahał się od blisko 9\% w Lednogórze do 18\% w Klukach. Publiczność muzeów skansenowskich w latach 1984-1988 składała się więc przede wszystkim ze zwiedzających w grupach zorganizowanych (zwykle 70-85\%). Jedynie w Chorzowie proporcje 
pomiędzy zorganizowanymi a indywidualnymi turystami były w miarę równomierne (odpowiednio: $52,9 \%$ i $47,1 \%$ ).

Struktura zwiedzających nie jest jednak stała i na początku lat dziewięćdziesiątych uległa znacznym przeobrażeniom. Zmiany struktury publiczności jednoznacznie wskazują na rosnące znaczenie indywidualnych zwiedzających (rys. 3). Największy przyrost tej części widowni zaobserwowano w Tokarni
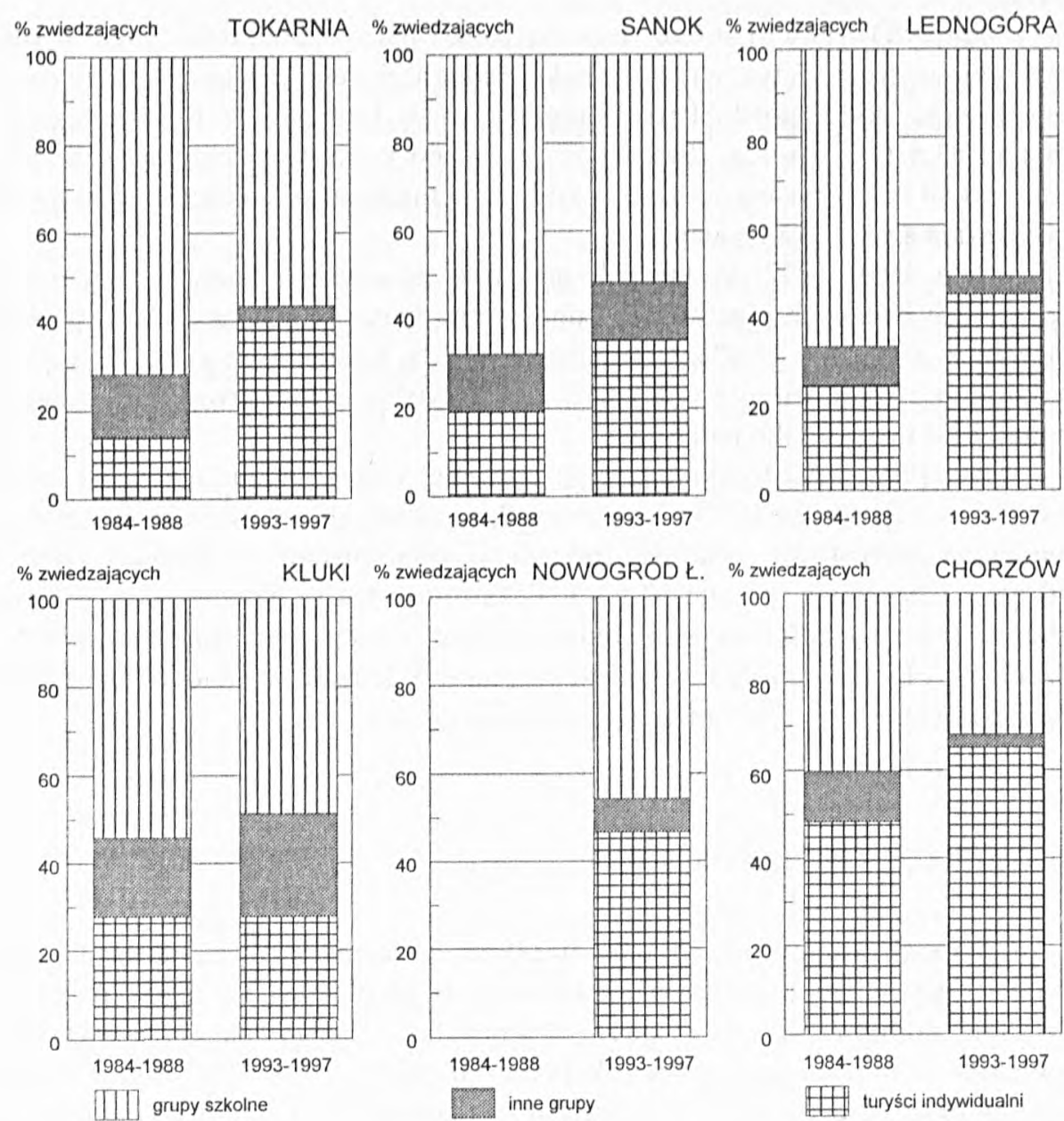

Rys. 3. Struktura zwiedzających wybrane skanseny w Polsce w latach 1984-1988 i 1993-1997 (opracowanie wlasne na podstawie informacji dyrekcji muzeów)

Dessin 3. La structure des visiteurs des musées ethnographiques choisis en Pologne dans les années 1984-1988 et 1993-1997

(élaboration propre à la base des informations fournies par la direction des musées) 
(o ponad 1/4). W Chorzowie, Lednogórze i Sanoku był on również znaczny i kształtował się na poziomie 15-20\%. W rezultacie wyraźnie spadł odsetek zwiedzających w grupach zorganizowanych (w przypadku Chorzowa nawet poniżej $40 \%$ !). Zjawisko to niewątpliwie należy wiązać ze zmniejszeniem udziału dzieci i młodzieży w grupach szkolnych (o kilkanaście procent) i poważnym ograniczeniem liczby imprez $\mathrm{w}$ ramach tzw. turystyki socjalnej. $\mathrm{Z}$ analizy liczb bezwzględnych wynika jednak, iż zmiany struktury są również rezultatem stałego wzrostu liczby indywidualnych zwiedzających (S t a s i a k 1998a).

Opisane powyżej zmiany struktury zwiedzających dotyczą wszystkich badanych skansenów, oprócz Muzeum Wsi Słowińskiej w Klukach. W placówce tej, jako jedynej, udział indywidualnych widzów niemal nie zmienił się, wyraźnie za to wzrósł odsetek zwiedzających w innych grupach (o 5,6\%). Nie są to jednak te same grupy. Miejsce wycieczek zakładowych z lat osiemdziesiątych zajęły wycieczki organizowane przez firmy turystyczne z Ustki lub Leby dla wczasowiczów wypoczywających w nadmorskich kurortach. W praktyce są więc to indywidualni widzowie zorganizowani ad hoc w ,jednorazową" grupę turystyczną.

W celu wyeliminowania przypadkowych, jednorocznych zmian struktury publiczności dotychczasowa analiza oparta została na średnich wartościach dla okresów pięcioletnich. Nie zawsze jednak oddaje ona wszystkie rzeczywiste zmiany. W przypadku Kurpiowskiego Parku Etnograficznego w Nowogrodzie Łomżyńskim mamy do czynienia z ciekawych zjawiskiem „odwrócenia” struktury zwiedzających (rys. 4). W ciągu ośmiu lat udział zwiedzających w grupach zorganizowanych spadł z blisko $75 \%$ w 1990 r. do $45 \%$ w 1997 r., mimo wyraźnego wzrostu w liczbach bezwzględnych (o ok. 6,5 tys.). Jednak znacznie szybszy wzrost liczby indywidualnych turystów sprawił, iż właśnie oni stali się najliczniejszą częścią publiczności muzealnej (ok. 55\%). Jeszcze większe dysproporcje między tymi dwoma typami widzów widoczne są w Górnośląskim Parku Etnograficznym w Chorzowie. W 1997 r. indywidualni zwiedzający stanowili aż $70 \%$ wszystkich osób, które odwiedziły skansen. W najbliższym czasie można spodziewać się podobnego „odwrócenia” struktury również i w pozostałych muzeach skansenowskich (Lednogórze, Sanoku i Tokarni). Tendencja do stopniowej dominacji turystyki indywidualnej wydaje się bowiem być trwała (choćby tylko z powodu rozwoju motoryzacji i wzrostu mobilności społeczeństwa).

Zaobserwowane zmiany struktury zwiedzających nie są charakterystyczne jedynie dla placówek skansenowskich. Wzrost znaczenia indywidualnych turystów wśród publiczności muzealnej zarejestrowano po $1990 \mathrm{r}$. także w innych muzeach (por. Z i e m b i ń s k i 1994). Wydaje się jednak, że jest to zjawisko dość korzystne. J. Z i e m b i ń s k i (1994) podkreśla, że wzrost liczby zwiedzających w grupach „,towarzyskich” czy „,rodzinnych” wiąże się ze zdecydowanie lepszą percepcją zbiorów niż podczas wycieczek szkolnych. Są to bowiem osoby świadomie dokonujące wyboru muzeum do zwiedzania, zainteresowane 


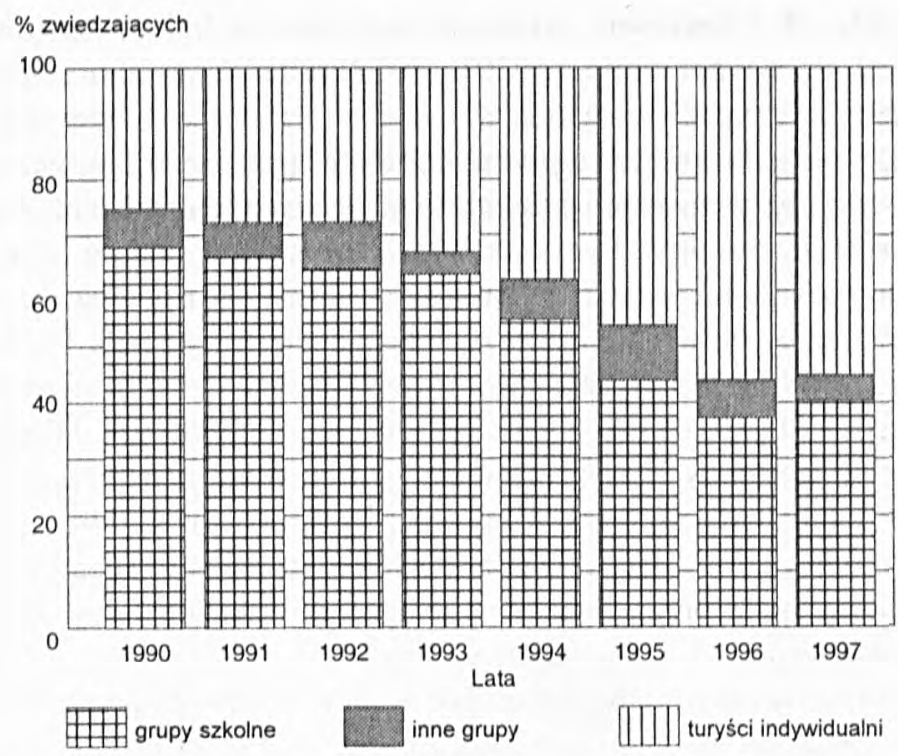

Rys. 4. Struktura zwiedzających Skansen Kurpiowski w Nowogrodzie Lomż. w latach 1990-1997 (opracowanie własne na podstawie informacji dyrekcji muzeum)

Dessin 4. La structure des visiteurs du Musée Ethnographique de Kurpie à Nowogród Lomżyński dans les années 1990-1997 (élaboration propre à la base des informations du musće)

tematyką ekspozycji i mające często już pewne przygotowanie do odbioru prezentowanych treści.

Duże ,rozdrobnienie” publiczności stwarza jednak poważny problem obsługi takich kilkuosobowych grup zwiedzających, zwłaszcza w przypadku wielkopowierzchniowych muzeów skansenowskich.

\section{SEZONOWOŚĆ RUCHU TURYSTYCZNEGO}

Większość dużych muzeów skansenowskich w Polsce otwartych jest przez cały rok. Mimo to, już sama specyfika ekspozycji na wolnym powietrzu stwarza w naszym klimacie oczywiste ograniczenia możliwości zwiedzania tych placówek. Duży wpływ warunków pogodowych zaznacza się bardzo nierównomiernym rozłożeniem liczby zwiedzających w ciaggu roku, miesiąca, tygodnia, a nawet dnia.

Wahania frekwencji w muzeach skansenowskich w ujęciu rocznym nawiązują w ogólnym zarysie do okresów wyznaczonych przez A. G e r l a c h - J ó s ef i c z (1975): 
- sezon „martwy” obejmuje miesiące zimowe i wczesnowiosenne (listopadkwiecień), choć bardzo często inauguracją działalności skansenu jest pierwszy dzień wiosny,

- sezon przejściowy to głównie miesiące jesienne (wrzesień, październik),

- właściwy sezon turystyczny w miesiącach późnowiosennych i letnich (maj -sierpień).

W celu porównania rozkładów frekwencji w wybranych muzeach skansenowskich w latach 1995-1997 obliczono współczynnik sezonowości (K a c z m a re k, L is ze w s k i 1989) ${ }^{2}$.

W Górnośląskim Parku Etnograficznym współczynnik sezonowości przyjmuje najniższe wartości (tylko raz - w czerwcu-przekracza 200\%). Przez sześć miesięcy (od maja do października) utrzymuje się jednak na poziomie powyżej $100 \%$ (rys. 5). Jest to bez wątpienia efekt oddziaływania konurbacji górnośląskiej zapewniającej w miarę równomierny dopływ zwiedzających od wiosny do jesieni (wycieczki szkolne, stali mieszkańcy, przyjezdni).

Równie długi sezon turystyczny ma miejsce w Muzeum Budownictwa Ludowego w Sanoku (rys. 5). Dzieli się on jednak na dwie wyraźne części: majsierpień (średni współczynnik sezonowości 215-250\%) oraz wrzesień-październik (współczynnik sezonowości w granicach 100\%). Sezon główny związany jest $\mathrm{z}$ wizytami w skansenie uczestników wycieczek szkolnych, wakacyjnych obozów, a także turystów wypoczywających w Bieszczadach. W rezultacie nałożenia się indywidualnego i zorganizowanego ruchu turystycznego absolutne maksimum przypada na sierpień. W pozostałych miesiącach natężenie ruchu turystycznego jest jednak tylko nieznacznie niższe. Liczba zwiedzających zmniejsza się zdecydowanie dopiero we wrześniu i październiku. Publiczność muzeum stanowią wtedy przede wszystkim wycieczki szkolne.

W pozostalych dwu placówkach sezon turystyczny jest znacznie krótszy i trwa jedynie cztery miesiące (od maja do sierpnia).

W Kurpiowskim Parku Etnograficznym w Nowogrodzie Łomżyńskim średni współczynnik sezonowości w latach 1995-1997 osiągnął najwyższą wartość (344\%) wśród analizowanych skansenów (rys. 5). Tak wyraźny szczyt przypada $\mathrm{w}$ czerwcu, co ma niewatpliwie związek $\mathrm{z}$ dużym natężeniem wycieczek szkolnych w tym miesiącu. W miesiącach letnich liczba widzów jest mniejsza, ale średni współczynnik sezonowości nadal przekracza $200 \%$. Tym razem są to głównie indywidualni zwiedzający podróżujący na Mazury w celach wakacyjno-urlopowych lub mieszkańcy Łomży, Ostrołęki i Warszawy, poszukujący wypoczynku w Puszczy Zielonej. Powakacyjne wycieczki szkolne nie odgrywają tutaj większej roli.

${ }^{2}$ Wspólczynnik sezonowości wyliczono z wzoru: $W_{S}=\left(x_{i} / x_{s r}\right) \times 100$, gdzie: $W_{S}-$ współczynnik sezonowości, $x_{i}$ - liczba zwiedzających w kolejnym miesiącu, $x_{\dot{s} r}$ - średnia miesięczna liczba zwiedzających. 


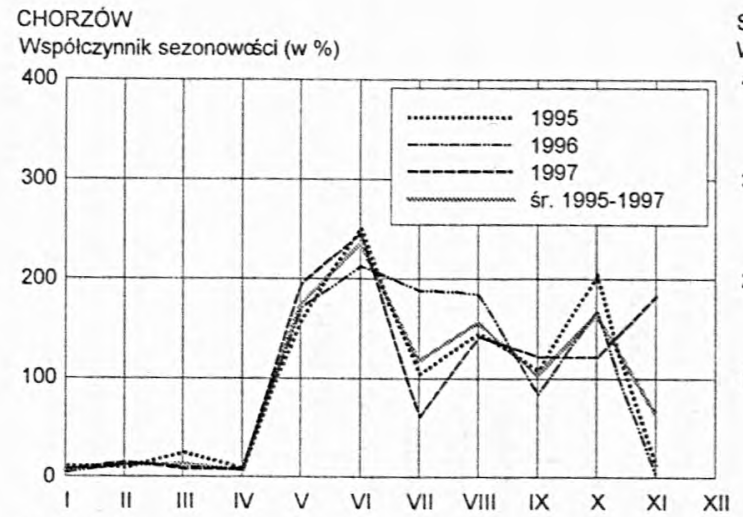

SANOK

Współczynnik sezonowości ( $w$ \%)

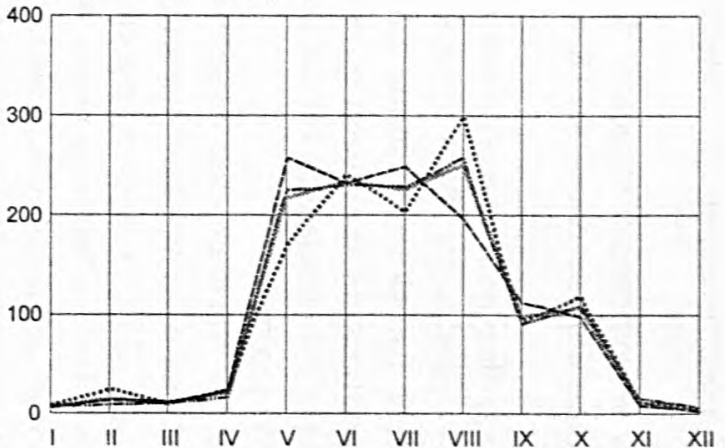

LEDNOGÓRA

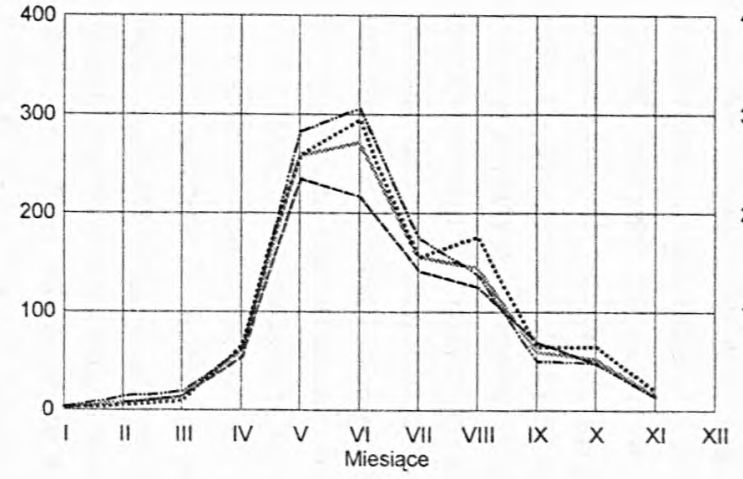

NOWOGRÓD

Rys. 5. Sezonowość ruchu turystycznego w wybranych skansenach w latach 1995-1997 (opracowanie własne na podstawie informacji dyrekcji muzeów)

Dessin 5. La caractére saisonnier du mouvement touristique dans les musées ethnographiques choisis dans les années 1995-1997 ( élaboration propre à la base des informations fournies par la direction des musées) 
W Wielkopolskim Parku Etnograficznym w Lednogórze-Dziekanowicach szczyt sezonu również przypada w czerwcu (rys. 5). Jest jednak znacznie mniej wyraźny niż w Nowogrodzie. Po pierwsze średni współczynnik sezonowości jedynie nieznacznie przekracza $270 \%$, po drugie - równie duże natężenie ruchu turystycznego występuje w maju (257\%). Taki rozkład frekwencji wynika przede wszystkim z położenia skansenu na Szlaku Piastowskim, zapewniającego przez dwa miesiące stały napływ dzieci i młodzieży szkolnej.

W okresie wakacyjnym publiczność muzeum stanowią tylko mieszkańcy Poznania i Gniezna (krótkie wyjazdy rekreacyjne w okolice miasta) oraz podróżni udający się na wypoczynek urlopowy nad morze. Stąd stosunkowo niskie wartości współczynnika sezonowości w lipcu i sierpniu (145-156\%).

Analiza rzeczywistych wartości współczynnika w poszczególnych latach, jak i wartości średnich dla całego analizowanego okresu, dowodzi istnienia dość istotnych różnic w rozkładzie frekwencji. W muzeach, w których dominują wycieczki szkolne wyraźnie zaznacza się maksimum w czerwcu (lub ewentualnie w maju), w placówkach położonych w typowych miejscowościach turystycznych szczyt sezonu przypada na miesiące wakacyjne. $Z$ kolei skanseny miejskie charakteryzują się długim sezonem i stosunkowo niewielką amplitudą wahań liczby zwiedzających.

Porównanie wykresów średniego współczynnika sezonowości dla lat 19911993 i 1995-1997 (rys. 6) dowodzi, iż zaszly dość istotne zmiany rozkładu zwiedzających w MBL w Sanoku (S t a s i a k 1999). Wyraźnie widoczne jest wydłużenie głównego sezonu turystycznego, objawiające się spłaszczeniem krzywej i zmniejszeniem wahań współczynnika sezonowości w miesiącach letnich. Maksymalne wartości współczynnika nie zmieniły się, pozostając na poziomie ok. $250 \%$. Doszło natomiast do przesunięcia maksimum natężenia frekwencji z czerwca (1991-1993) na sierpień (1995-1997). Ponieważ jednak wszystkie miesiące letnie charakteryzują się podobnymi wartościami, prawdopodobnie zwiastuje to wydłużenie głównego sezonu turystycznego od maja do sierpnia. Tymczasem coraz mniejszą rolę odgrywa drugie, październikowe maksimum. O ile w latach 1991-1993 współczynnik sezonowości dla tego miesiąca wynosił ok. $150 \%$, to w następnych latach ksztaltował się na poziomie niewiele ponad $100 \%$.

Podobne procesy zaobserwowano także w Kurpiowskim Parku Etnograficznym w Nowogrodzie Lomżyńskim (rys. 6). Maksimum ruchu turystycznego co prawda wciąż przypada na czerwiec (wartość średniego współczynnika sezonowości oscyluje w granicach $340 \%$ ), ale w ciągu kilku lat nastąpił bardzo duży wzrost udziału turystów odwiedzających skansen w miesiącach letnich. Współczynnik sezonowości osiągnął w lipcu niemal 230\%, a w sierpniu prawie $250 \%$. Jednocześnie wyraźnie zmalało znaczenie maja (spadek o 86\%) oraz podobnie jak w Sanoku - doszło do likwidacji październikowego szczytu zwiedzających (spadek do poziomu 80\%). 
Współczynnik sezonowości (w \%)

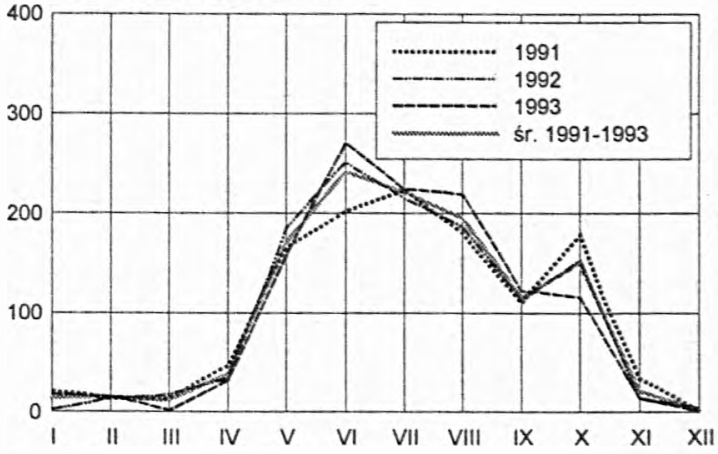

SANOK

Współczynnik sezonowości ( $w \%)$

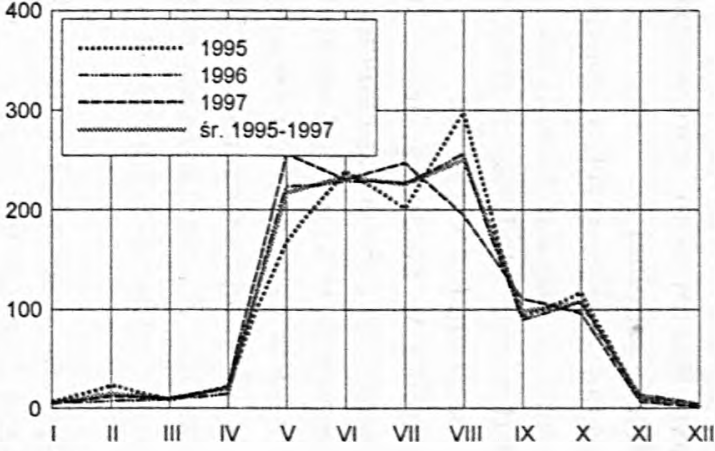

NOWOGRÓD

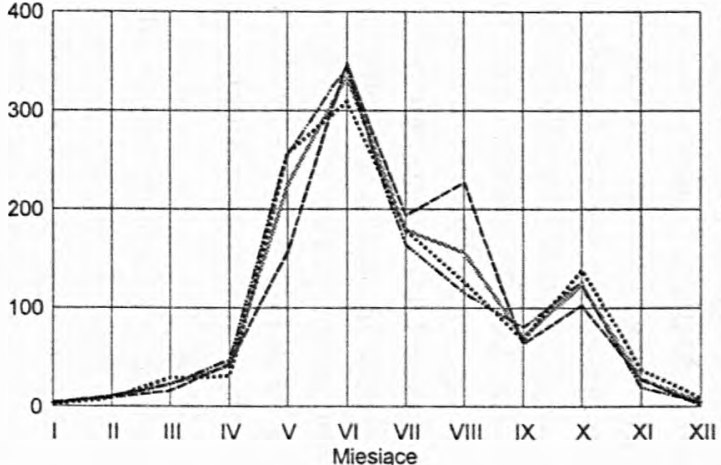

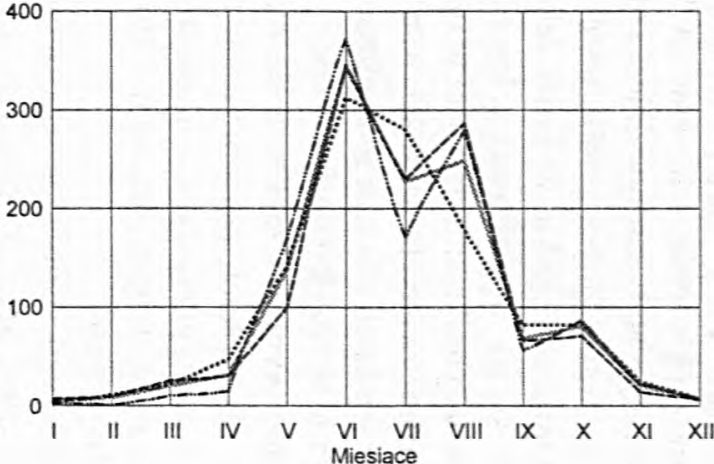

Rys. 6. Zmiany sezonowości w wybranych skansenach w latach 1991-1993 i 1995-1997 (opracowanie wlasne na podstawie informacji dyrekcji muzeów)

Dessin 6. Les changements du caractére saisonnier dans les musées ethnographiques choisis dans les années 1991-1993 et 1995-1997 (élaboration propre à la base des informations fournies par la direction des musées) 
Oba te zjawiska (zanikanie jesiennego szczytu i wydłużenie letniego sezonu) są bez wątpienia odzwierciedleniem rosnącego znaczenia wśród publiczności muzealnej turystów indywidualnych.

Zebrane przez autora informacje dowodzą dużego zróżnicowania analizowanych placówek także pod względem tygodniowego i dziennego rozkładu frekwencji ${ }^{3}$. Na zmiany natężenia ruchu turystycznego $\mathrm{w}$ tak krótkich okresach czasu ma wpływ wiele, niekiedy bardzo trudnych do identyfikacji czynników. Do najważniejszych z nich należy zaliczyć:

- miesiąc roku (sezon wycieczkowy lub urlopowy, por. rys. 7),

- pogodę,

- lokalizację muzeum (w regionie turystycznym, na terenie dużego miasta, przy ważnych szlakach komunikacyjnych i turystycznych),

- obecność innych atrakcji turystycznych (morze, góry, zabytki, muzea),

- imprezy kulturalne organizowane na terenie skansenu,

- zagospodarowanie turystyczne (baza gastronomiczna).
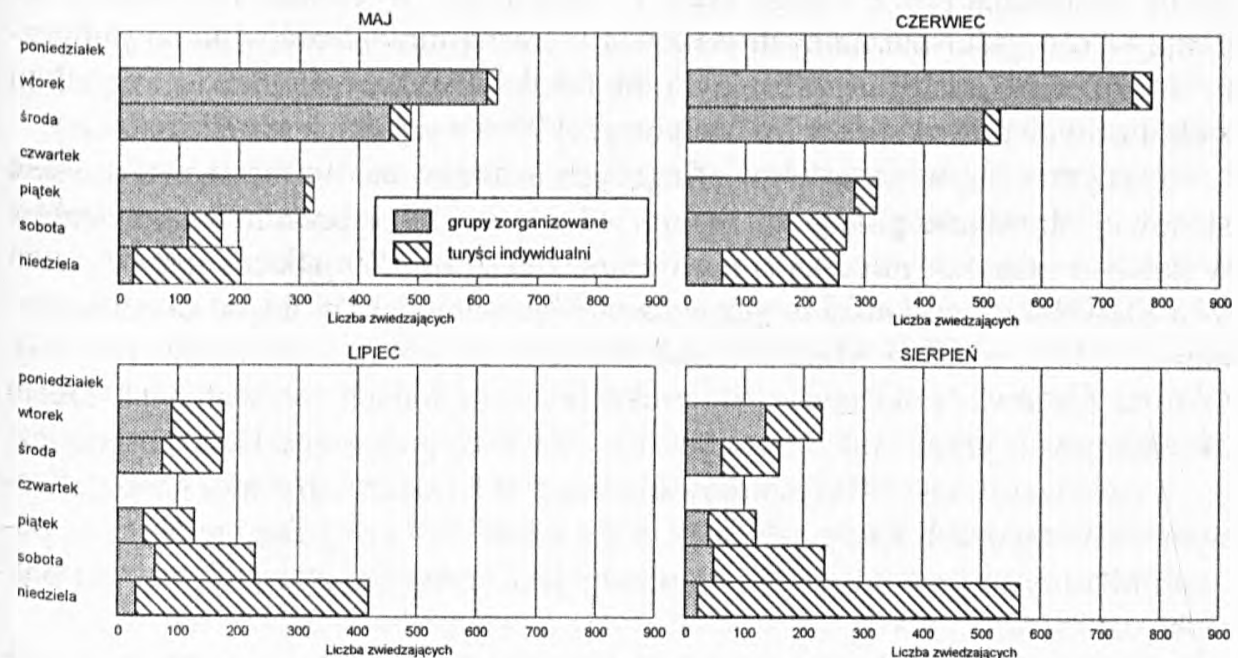

Rys. 7. Średnia frekwencja w poszczególnych dniach tygodnia sezonu turystycznego w Wielkopolskim Parku Etnograficznym w Lednogórze w 1997 r.

(opracowanie własne na podstawie informacji dyrekcji muzeum)

Dessin 7. La fréquence moyenne les jours particuliers de la semaine pendant la saison touristique dans le Parc Ethnographique de Wielkopolska à Lednogóra

(élaboration propre à la base des informations fournies par la direction du musée)

3 Analiza zmian natężenia ruchu turystycznego w ujęciu tygodniowym i dziennym oparta zostala na obserwacjach autora podczas badań terenowych, nielicznych i niepełnych danych statystycznych (tylko WPE w Lednogórze odnotowuje dzienną frekwencję) oraz przede wszystkim na wywiadach $\mathrm{z}$ długoletnimi pracownikami skansenów. 
Odrębne zagadnienie stanowi czas otwarcia placówek muzealnych. Teoretycznie powinien on być dostosowany do zapotrzebowania i oczekiwań potencjalnych zwiedzających. W rzeczywistości, z różnych względów (ekonomicznych, organizacyjnych), czas pracy muzeów ustalany jest raz w roku, bez możliwości okresowych modyfikacji. Brak dopasowania do zmian charakteru ruchu turystycznego ma również istotny wpływ na rozkład frekwencji w ciagu dnia. Objawia się to $\mathrm{m}$. in. powstawaniem w okresie wakacyjnym "martwych" okresów w godzinach porannych, czy też koniecznością rezygnacji ze zwiedzania przez wielu chętnych z powodu zbyt wczesnego zamykania muzeum.

\section{ZASIĘG PRZESTRZENNEGO ODDZIALYWANIA}

O znaczeniu danego muzeum w dużej mierze świadczy zasięg jego przestrzennego oddziaływania. Placówki o wysokiej randze przyciagają znacząca liczbę zwiedzających z całego kraju i z zagranicy. W efekcie mieszkańcy regionu wśród gości muzealnych stanowią wyraźną mniejszość. Z kolei publiczność muzeów o zasięgu regionalnym lub lokalnym składa się przede wszystkim z okolicznych mieszkańców (nawet powyżej $90 \%$ wszystkich zwiedzających).

Zdecydowaną większość zwiedzających analizowane muzea skansenowskie stanowia obywatele polscy. $\mathrm{Z}$ reguly jedynie po kilka procent respondentów w każdym muzeum mieszkało poza granicami kraju. Wyjątkiem jest Muzeum Wsi Słowińskiej w Klukach, gdzie zanotowano największy udział obcokrajowców (15,4\%), a także Muzeum Budownictwa Ludowego w Sanoku (12,5\%). Obie te placówki położone są w atrakcyjnych regionach turystycznych często odwiedzanych przez cudzoziemców. Co ciekawe, podobny odsetek zagranicznych zwiedzających (18\%) odnotowano także w Kaszubskim Parku Etnograficznym we Wdzydzach Kiszewskich (R o d a c k a 1997). Wydaje się więc, że poziom kilkunastu procent gości z zagranicy jest maksymalnym pułapem dla polskich skansenów.

Trzeba jednak przy tym pamiętać, że badania prowadzone były w okresie wakacyjnym, a więc w czasie zwiększonego natężenia przyjazdów obcokrajowców. W skali roku udział cudzoziemców jest znacznie niższy, tym bardziej, że zagraniczny ruch turystyczny w skansenach ogranicza się przede wszystkim do indywidualnych zwiedzających. Muzea tego typu nie są raczej odwiedzane przez zorganizowane grupy cudzoziemców.

Badania ankietowe w Chorzowie i Lednogórze nie objęły żadnej wycieczki obcokrajowców, natomiast w Tokarni nie zanotowano takiej grupy przez cały 1997 r. Inne skanseny zwiedzilo zaledwie po kilka-kilkanaście zagranicznych wycieczek, co stanowi zaledwie 1-2\% wszystkich grup zorganizowanych (tab. II). 
Tabela II

Udział turystów zagranicznych wśród publiczności wybranych skansenów w Polsce w latach 1996-1997

La participation des touristes étrangers parmi les visiteurs des musées ethnographiques choisis en Pologne dans les années 1996-1997

\begin{tabular}{|l|c|c|c|c|}
\hline \multirow{3}{*}{ Skansen } & \multicolumn{4}{|c|}{ Turyści zagraniczni } \\
\cline { 2 - 5 } & \multicolumn{2}{|c|}{ zwiedzający indywidualnie } & \multicolumn{2}{|c|}{ grupy zorganizowane } \\
\cline { 2 - 5 } & liczba osób & $\%$ & Liczba grup & $\%$ \\
\hline Chorzów & 5 & 2,31 & 0 & 0,00 \\
Kluki & 37 & 15,42 & 18 & 1,95 \\
Lednogóra & 23 & 7,32 & 0 & 0,00 \\
Nowogród & 17 & 9,34 & 7 & 2,18 \\
Sanok & 40 & 12,46 & 12 & 1,02 \\
Tokarnia & 17 & 8,37 & 0 & 0,00 \\
\hline
\end{tabular}

Ź r ó d l o: Opracowanie wlasne na podstawie badań ankietowych.

Według szacunków pracowników badanych skansenów cudzoziemcy w skali całego roku stanowią w Klukach ok. $10 \%$ ogółu turystów, w Sanoku co najwyżej $5-7 \%$, a w pozostałych muzeach po $2-5 \%$. Mimo niewielkiego udziału obcokrajowców wśród zwiedzających polskie skanseny warto przyjrzeć się bliżej strukturze narodowościowej tego typu muzealnych gości (tab. III).

Zagraniczni turyści, których objęły badania ankietowe, pochodzili z 19 krajów na czterech kontynentach (Afryka, Ameryka Północna, Australia, Europa). Prawie $90 \%$ obcokrajowców to mieszkańcy Europy (tab. III). Wśród nich zdecydowanie dominowali obywatele Niemiec (ok. 1/3). Znaczną część zwiedzających stanowili także Francuzi, Włosi, Holendrzy i Brytyjczycy. Pozostałe kraje europejskie reprezentowane były przez pojedynczych turystów.

Dość istotną grupą odwiedzających skanseny okazali się także mieszkańcy Australii, Kanady i Stanów Zjednoczonych. W większości były to osoby polskiego pochodzenia, odwiedzające po latach rodzinny kraj. Najwięcej przedstawicieli Polonii odnotowano na terenach historycznych masowych emigracji za ocean (Kurpie, Podkarpacie, Wielkopolska).

Analiza miejsc zamieszkania polskich turystów zwiedzających wybrane placówki skansenowskie prowadzi do wniosku, iż zasięgi przestrzennego oddziaływania poszczególnych muzeów są bardzo zróżnicowane.

Lokalny charakter posiada Górnośląski Park Etnograficzny w Chorzowie. Blisko $90 \%$ zwiedzających tę placówkę pochodzi z woj. katowickiego. Najliczniej reprezentowane są przy tym trzy miasta: Chorzów $(31,9 \%)$, Katowice $(21,3 \%)$ i Bytom $(9,7 \%)$. Łacznie pochodzi $z$ nich prawie $2 / 3$ indywidualnych turystów. Znaczna część z nich mieszka w dużych osiedlach mieszkaniowych 
T a b e I a III

Pochodzenie zagranicznych turystów zwiedzających wybrane polskie skanseny w latach 1996-1997

L’origine territoriale des touristes visitant les musées ethnographiques choisi dans les années 1996-1997

\begin{tabular}{|l|c|c|c|c|c|c|c|}
\hline \multirow{2}{*}{ Kraj } & \multicolumn{7}{|c|}{ Liczba zagranicznych zwiedzajacych } \\
\cline { 2 - 8 } & Chorzów & Kluki & Lednogóra & Nowogród & Sanok & Tokarnia & Razem \\
\hline Austria & - & - & 1 & - & 1 & - & 2 \\
Australia & - & - & 1 & 1 & 1 & 1 & 4 \\
Belgia & - & 1 & 2 & - & 1 & 1 & 5 \\
Czechy & - & 1 & - & - & - & - & 1 \\
Finlandia & - & - & - & 1 & - & - & 1 \\
Francja & 1 & 5 & 3 & - & 10 & 3 & 22 \\
Grecja & - & - & - & - & 1 & - & 1 \\
Holandia & 1 & 3 & 1 & 2 & 2 & 1 & 10 \\
Kanada & - & - & - & 1 & - & 2 & 3 \\
Niemcy & 3 & 23 & 9 & 4 & 10 & 4 & 43 \\
Macedonia & - & - & 1 & - & - & - & 1 \\
Rosja & - & - & - & 1 & - & - & 1 \\
Szwajcaria & - & 1 & - & - & - & - & 1 \\
Szwecja & - & - & 1 & - & - & - & 1 \\
Togo & - & - & - & 1 & - & - & 1 \\
Ukraina & - & - & - & - & 1 & - & 1 \\
USA & - & - & 2 & 4 & 1 & 2 & 9 \\
Włochy & - & 2 & 1 & 1 & 9 & 1 & 14 \\
Wielka Brytania & - & 1 & 1 & 1 & 3 & 1 & 7 \\
\hline Razem & 5 & 37 & 23 & 17 & 40 & 17 & 139 \\
\hline
\end{tabular}

Ź r ó d ło: Opracowanie własne na podstawie badań ankietowych.

położonych w promieniu 3 kilometrów od skansenu (np. Osiedle Tysiąclecia w Katowicach). Około 4/5 odwiedzających Górnośląski Park Etnograficzny pokonało mniej niż $20 \mathrm{~km}$ (strefa zasięgu świątecznego). Uzyskane wyniki pokrywają się dość dokładnie ze strefami oddziaływania całego Wojewódzkiego Parku Kultury i Wypoczynku (D u d e k 1995).

Równie wysoka koncentracja zwiedzających ma miejsce w przypadku zorganizowanego ruchu turystycznego. Na 75 ankietowanych grup jedynie trzy nie pochodziły z województwa katowickiego. Chorzowski skansen odwiedzały przede wszystkim wycieczki z Katowic (32\%), Bytomia (13,3\%), Siemianowic i Chorzowa (po 9,3\%).

Znacznie szerszy zasięg oddziaływania posiada natomiast Wielkopolski Park Etnograficzny w Lednogórze-Dziekanowicach. Podstawową część publiczności tego muzeum stanowią mieszkańcy szeroko rozumianej Wielkopolski (rys. 8). 


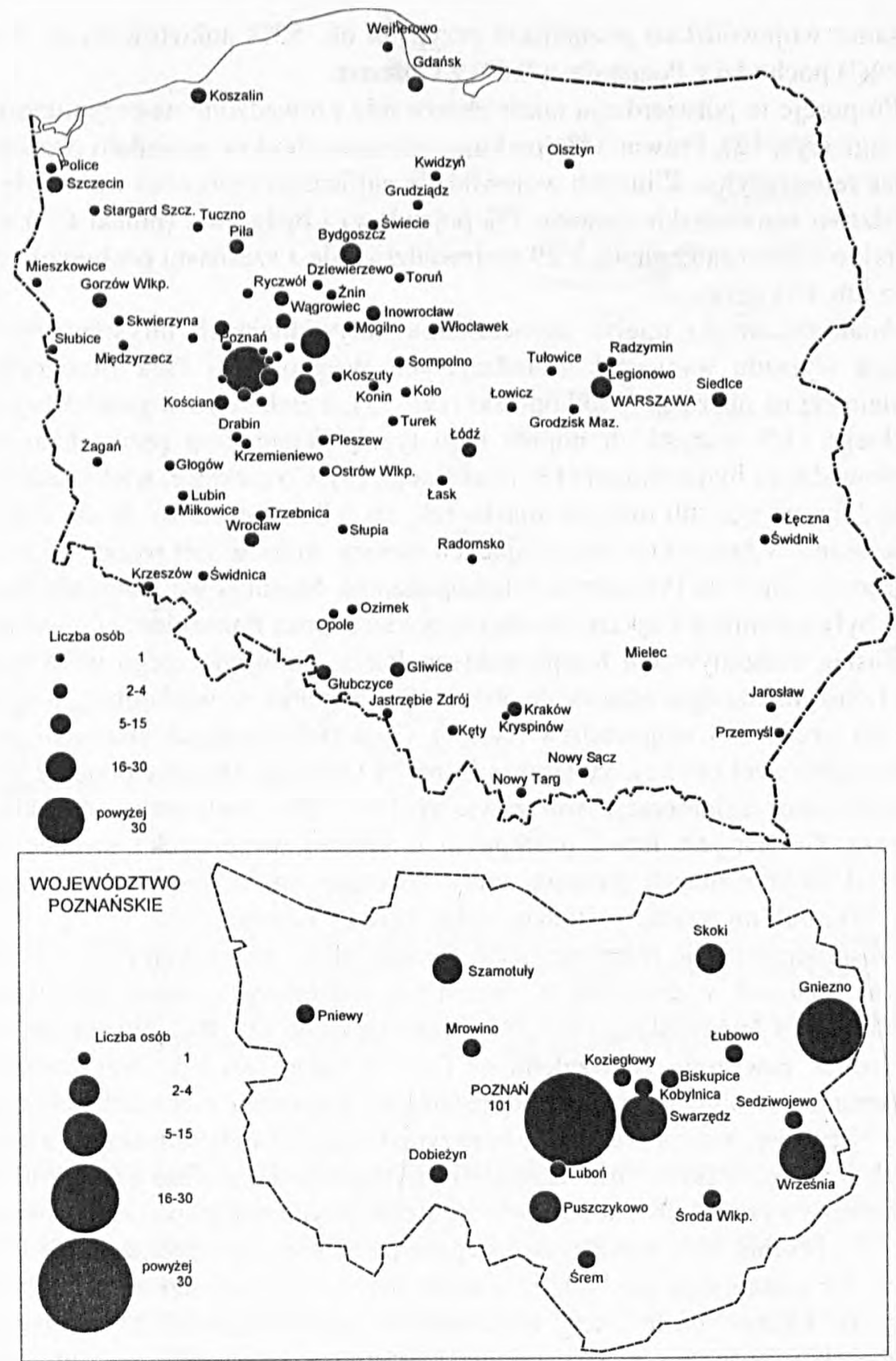

Rys. 8. Miejsce zamieszkania turystów indywidualnych zwiedzających WPE w Lednogórze w 1997 r. (S t a s i a k 1998a)

Dessin 8. Le lieur ordinaire d'habitation des touristes individuels visitant le Parc Ethnographique de Wielkopolska à Lednogóra en 1997 (S t a s i a k 1998a) 
Na samo województwo poznańskie przypada ok. $52 \%$ ankietowanych, w tym $32,1 \%($ !) pochodzi z Poznania, a 8,6\% z Gniezna.

Proporcje te potwierdzają także obserwacje prowadzone na przymuzealnym parkingu (rys. 12). Prawie 54\% parkujących samochodów posiadało poznańskie tablice rejestracyjne. $Z$ innych województw najliczniej reprezentowane było województwo warszawskie (prawie 7\% pojazdów) i bydgoskie (ponad 6\%). Ogółem odnotowano samochody z 29 województw (ale z szesnastu pochodziło tylko jedno lub dwa auta).

Analogicznie do miejsc zamieszkania indywidualnych turystów, również miejsca wyjazdu wycieczek zwiedzających Wielkopolski Park Etnograficzny skupiają się na obszarze Wielkopolski (rys. 13), a zwłaszcza województwa poznańskiego (1/3 wszystkich imprez tego typu). Wiele grup przyjechało także z województwa bydgoskiego (13) i kaliskiego (9). Co ciekawe, większość z nich pochodziła ze wsi lub małych miasteczek, co tylko częściowo da się połączyć z miejscami wypoczynku zwiedzających (obozy, kolonie lub wczasy w małych miejscowościach na Pojezierzu Wielkopolskim). Stosunkowo słabo reprezentowane były natomiast większe miasta (oczywiście poza Poznaniem i Gnieznem).

Zasięg oddziaływania Kurpiowskiego Parku Etnograficznego w Nowogrodzie Łomżyńskim ogranicza się do obszaru Polski północno-wschodniej, a w praktyce do terenu 3-4 województw (rys. 9). Gros zwiedzajacych stanowili mieszkańcy najbliższej okolicy, zwłaszcza Łomży i Ostrołęki (łącznie ponad 23\% badanych) oraz aglomeracji warszawskiej (ok. 20\% badanych), dla których Puszcza Zielona jest łatwo dostępnym miejscem wypoczynku świątecznego. Spośród innych dużych polskich miast znaczący udział wśród ankietowanych (ok. 3\%) mieli mieszkańcy Białegostoku, Lodzi i Trójmiasta.

Obserwacje tablic rejestracyjnych samochodów osobowych (rys. 12) wskazują na znacznie wyższy niż $\mathrm{w}$ badaniach ankietowych udział mieszkańców województwa łomżyńskiego $(21,5 \%)$ i ostrołęckiego (17,4\%). Wynik ten może być jednak zawyżony ze względu na fakt, iż wielu turystów przyjeżdżało do skansenu ze swoimi rodzinami pojazdami na lokalnych numerach rejestracyjnych. Niemniej, można szacować, że przynajmniej $2 / 3$ indywidualnych zwiedzających w Kurpiowskim Parku Etnograficznym pochodzi z Mazowsza i Podlasia.

Jeszcze wyższa koncentracja występuje w przypadku grup zorganizowanych (rys. 13). Niemal $50 \%$ wycieczek przypada na województwo łomżyńskie i ostrołęckie. Co piąta grupa pochodziła z Białostocczyzny, a co dziesiąta - z Suwalszczyzny. Łącznie na te cztery województwa przypada ponad $80 \%$ wszystkich wycieczek w Skansenie Kurpiowskim. Interesujące, że muzeum cieszyło się stosunkowo bardzo niską popularnością grup zorganizowanych $\mathrm{z}$ województwa warszawskiego (tylko 7,4\%).

Województwa spoza Polski północno-wschodniej reprezentowane były sporadycznie. Należy jedynie wspomnieć o kilku grupach z Górnego Śląska, co wiązało się z sierpniową powodzią w tej części kraju (kolonie dla dzieci powodzian). 


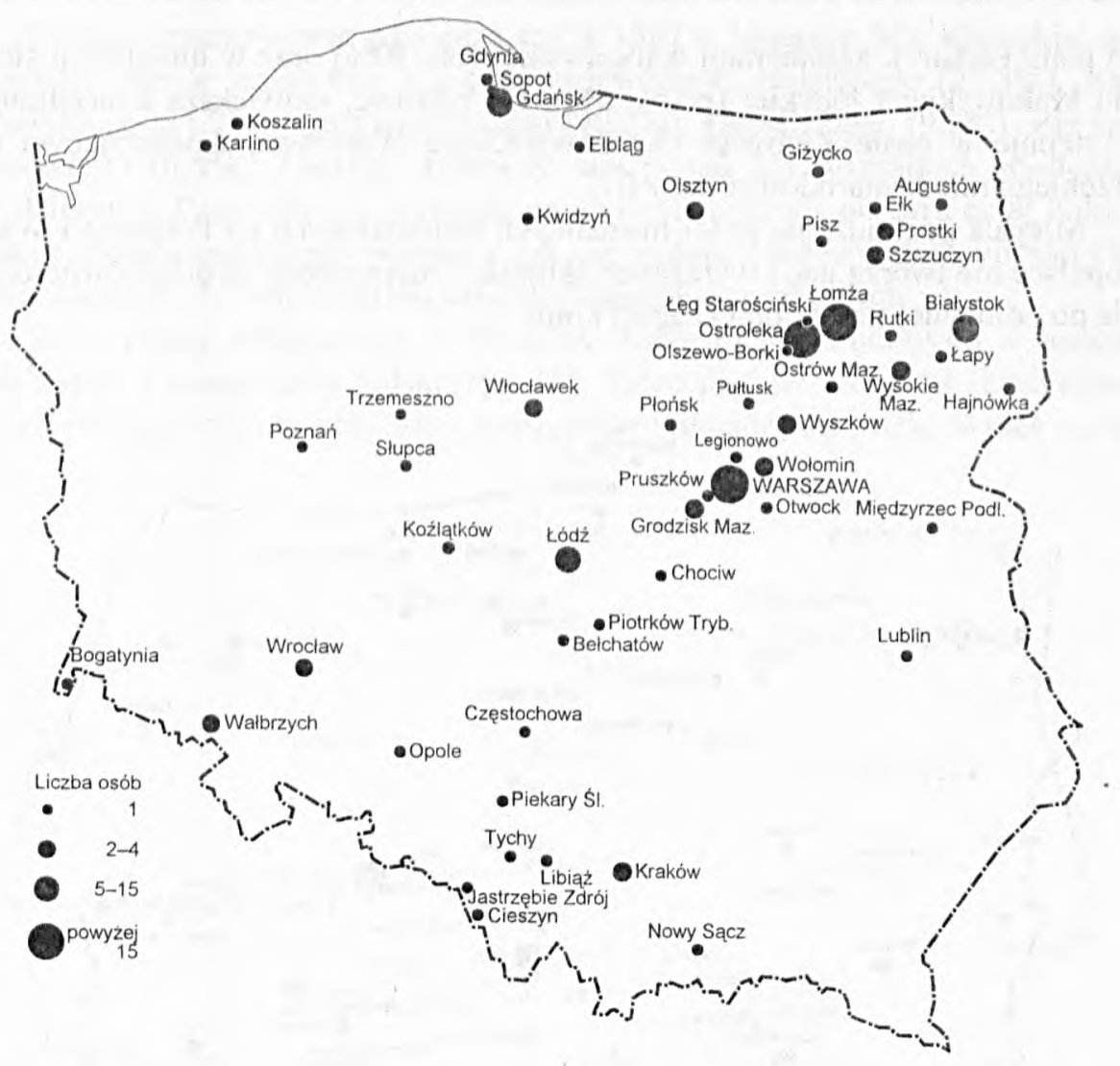

Rys, 9. Miejsca zamieszkania turystów indywidualnych zwiedzających KPE w Nowogrodzie Łomżyńskim w 1997 r. ( opracowanie własne na podstawie badań ankietowych)

Dessin 9. La lieu ordinaire d'habitation des touristes individuels visitant le Parc Ethnographique de Kurpie à Nowogród Łomżyński en 1997 (élaboration propre à la base d'enquêtes)

Publiczność Parku Etnograficznego w Tokarni wywodziła się z 36 województw (rys. 10). Brakowało mieszkańców województw Polski południowo-wschodniej i północno-wschodniej (w tym również z rolniczych województw północnego Mazowsza).

Najliczniej reprezentowane okazało się województwo kieleckie (ok. 25\% ankietowanych). Były to głównie osoby mieszkające w Kielcach (ponad 14\%), które trafily do muzeum w czasie krótkich wycieczek krajoznawczych po okolicy.

Miejsca zamieszkania pozostałych zwiedzających skansen koncentrują się przede wszystkim na obszarze Górnośląskiego Okręgu Przemysłowego (niemal 
co piąty badany), aglomeracji warszawskiej (ok. 10\%) oraz w mniejszym stopniu krakowskiej i łódzkiej (po ok. 6\%). Co ciekawe, największa koncentracja występuje w pasie Katowice (Kraków)-Kielce-Warszawa, nawiązującym do przebiegu międzynarodowej trasy E77.

Miejsca pochodzenia gości muzealnych zamieszkałych na Pomorzu i Wielkopolsce nie tworzą jakiś wyraźnych skupisk - rozproszone są dość równomiernie po północnej i zachodniej części kraju.

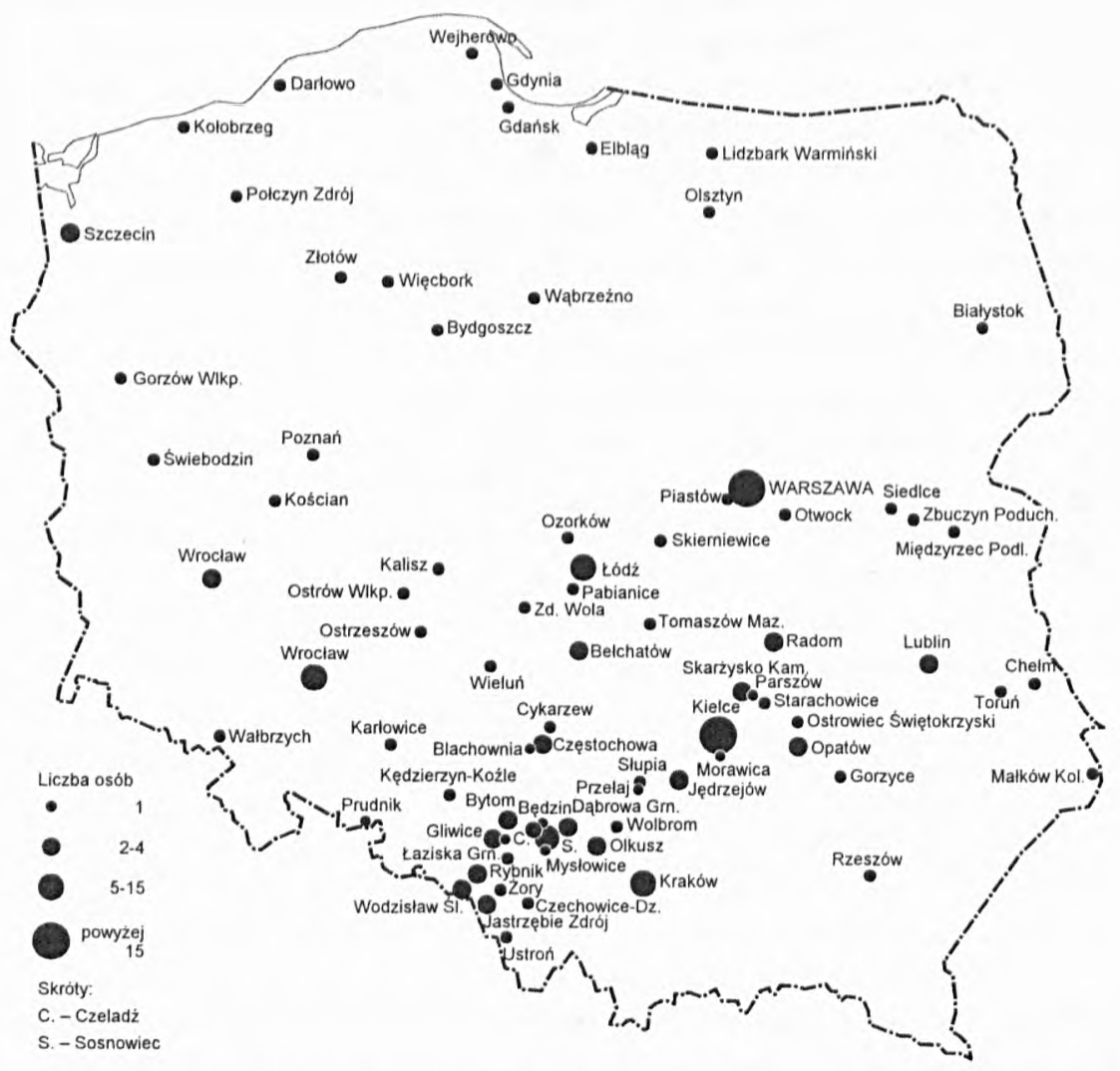

Rys. 10. Miejsca zamieszkania turystów indywidualnych zwiedzających MWK-PE w Tokarni w 1997 r. (opracowanie wlasne na podstawie badań ankietowych)

Dessin 10. La lieu ordinaire d'habitation des touristes individuels visitant le Parc Ethnographique à Tokarnia (élaboration propre à la base d'enquêtes)

Obserwacje tablic rejestracyjnych samochodów na parkingu przed muzeum wskazują jeszcze na dość istotne znaczenie turystów z województwa lubelskiego (powyżej 5\%). 
Grupy zorganizowane odwiedzające w 1997 r. Muzeum Wsi Kieleckiej pochodziły przede wszystkim z pięciu województw: kieleckiego $(29,3 \%)$, warszawskiego $(11,9 \%)$, częstochowskiego $(10,2 \%)$, katowickiego $(9,2 \%)$ oraz krakowskiego $(6,6 \%)$. Łącznie stanowiły one ponad $2 / 3$ wszystkich wycieczek w skansenie. Pozostała 1/3 przypada na 39 województw z obszaru całej Polsce. Taki rozkład przestrzenny wynika - jak się wydaje - z dużej atrakcyjności Gór Świętokrzyskich, zwłaszcza dla szkolnych grup wycieczkowych.

Zwiedzający ankietowani w Muzeum Budownictwa Ludowego w Sanoku pochodzili z terenu całej Polski (rys. 11). Tylko pięć województw (ciechanowskie, jeleniogórskie, leszczyńskie, łomżyńskie i płockie) nie miało swoich repre-

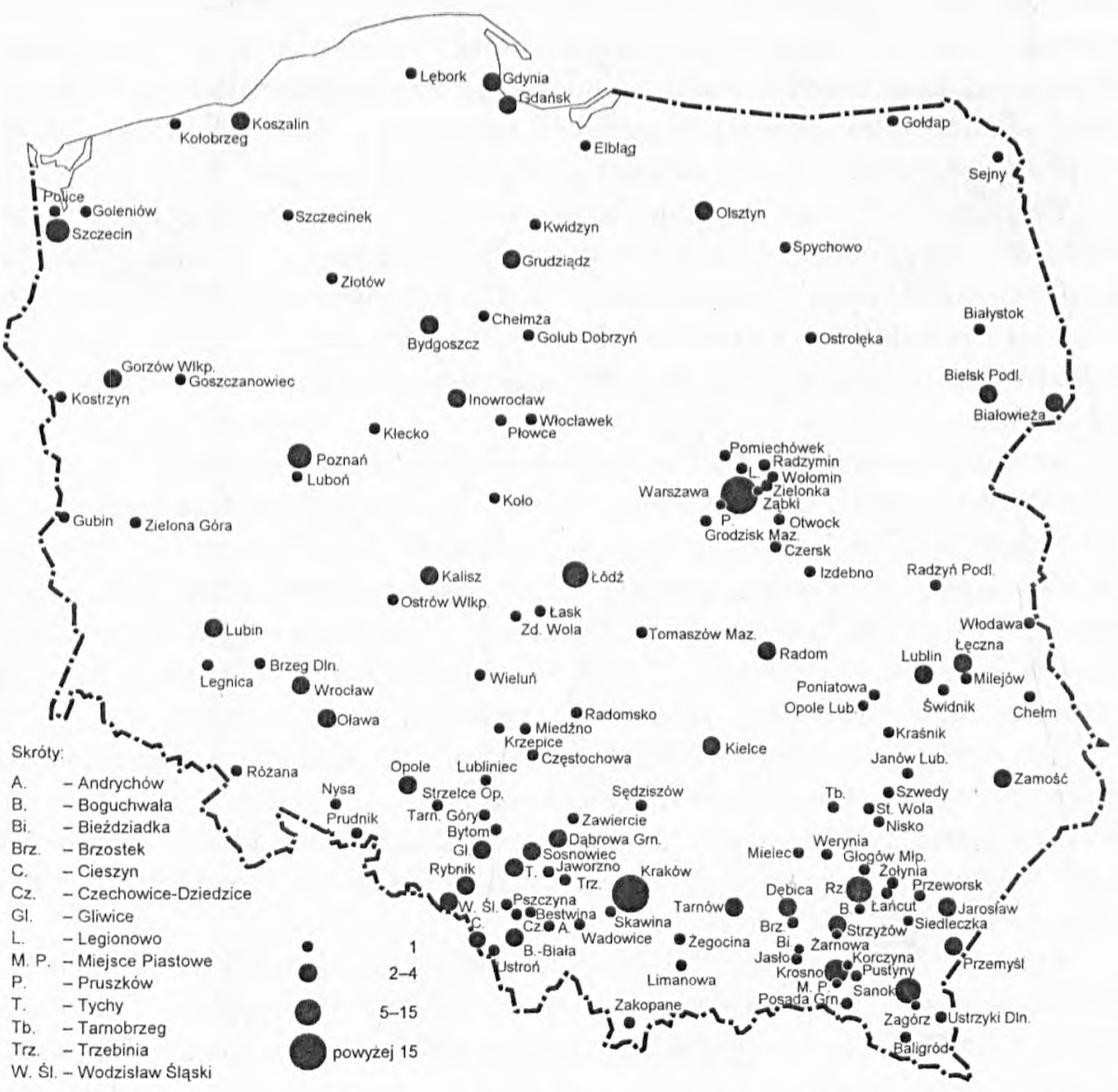

Rys. 11. Miejsca zamieszkania turystów indywidualnych zwiedzających MBL w Sanoku w 1997 r. (opracowanie własne na podstawie badań ankietowych)

Dessin 11. Le lieu ordinaire d'habitation des touristes individuels visitant le Parc de la Construction Populaire à Sanok en 1997 (élaboration propre à la base d'enquêtes) 
zentantów, z pozostałych 44 przybyła co najmniej jedna osoba. Miejsca zamieszkania ankietowanych nie są jednak rozmieszczone równomiernie. Występuje wyraźna koncentracja zwiedzających w trzech regionach. Są to:

- Polska południowo-wschodnia (województwa: krośnieńskie, przemyskie, rzeszowskie) - ok. $20 \%$,

- województwa: katowickie, krakowskie i bielskie - ok. 15\%,

- województwo warszawskie - ok. $9 \%$.

Dość znaczny udział miały również województwa lubelskie, łódzkie i szczecińskie (po ok. 3\%).

Publiczność skansenu w Sanoku składa się więc z dwóch rodzajów zwiedzających. Pierwszą grupę stanowią mieszkańcy regionu (województwo krośnieńskie i województwa ościenne), drugą natomiast - mieszkańcy dużych aglomeracji miejskich (katowickiej, krakowskiej, warszawskiej, a w mniejszym stopniu łódzkiej, szczecińskiej i trójmiejskiej). Zresztą zdecydowaną większość indywidualnych zwiedzających stanowili mieszkańcy miast (ok. 85\%). Dla turystów pochodzących ze wsi skansen nie był zbyt interesujący.

Parkujące przy muzeum samochody posiadały tablice rejestracyjne 43 województw z całej Polski (rys. 12). Dominowały jednak pojazdy z województw południowo-wschodnich (krośnieńskie - 18,6\%, przemyskie $-5,8 \%$, rzeszowskie $-4,8 \%$ ) i południowych (krakowskie - 11,3\%, katowickie - 9,3\%) oraz województwa stołecznego $(7,5 \%)$. W sumie stanowiły one ponad $57 \%$ wszystkich samochodów.

Interesująco przedstawia się także przestrzenny rozkład pochodzenia grup zwiedzających MBL w Sanoku (rys. 13). Wyraźnie dominują województwa Polski południowo-wschodniej, z których pochodziła niemal co trzecia wycieczka (krośnieńskie $-17,8 \%$, rzeszowskie $-7,6 \%$, przemyskie $-6,7 \%$ ). Stosunkowo dużo grup wywodziło się również z wielkich aglomeracji miejskich (woj. warszawskie $-7,8 \%$, katowickie $-7,1 \%$, woj. lubelskiego $(6,2 \%)$ oraz szeroko rozumianej Małopolski (woj. krakowskie, tarnowskie, tarnobrzeskie, kieleckie od 2 do 4,9\%). Najmniej wycieczek przyjechało do skansenu z najbardziej oddalonych rejonów Polski (powyżej $500 \mathrm{~km}$ ) oraz słabiej zurbanizowanych województw centralnych (kaliskie, konińskie, piotrkowskie, sieradzkie, skierniewickie). Niemniej wycieczki w $1997 \mathrm{r}$. pochodziły aż z 48 województw (bez woj. włocławskiego).

Podobny do sanockiego, ogólnokrajowy zasięg posiada także Muzeum Wsi Słowińskiej w Klukach. Ankietowani pochodzili z 45 województw całej Polski (oprócz chełmskiego, łomżyńskiego, przemyskiego i zamojskiego). Przeważali przy tym zwiedzający z województw „,miejskich”: warszawskiego (co dziesiąty), katowickiego, łódzkiego, poznańskiego, wrocławskiego. Dość znacznie reprezentowane były także województwa nadmorskie, Wielkopolska i Dolny Śląsk. O dużym rozproszeniu ruchu turystycznego świadczy fakt, iż udział zwiedzajacych z wszystkich tych województw wahał się w przedziale od 2 do $10 \%$ ogółu 


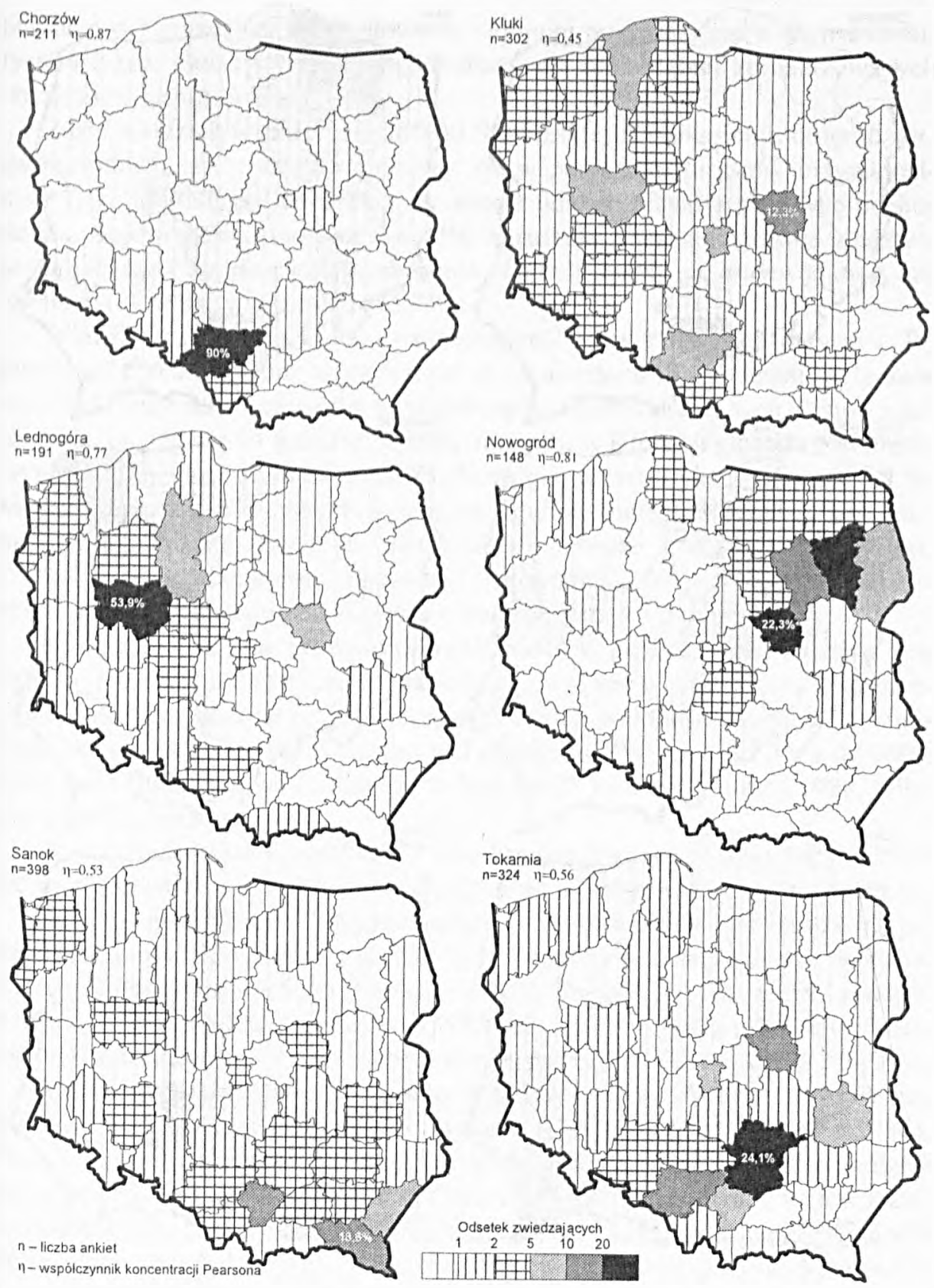

Rys. 12. Indywidualni zwiedzający wybrane skanseny w Polsce wg województw (opracowanie własne na podstawie tablic rejestracyjnych samochodów osobowych)

Dessin 12. Les visiteurs individueles des musées ethnographiques en Pologne selon les voïvodies (elaboration propre à la base des plaques d'immatriculation des voitures) 


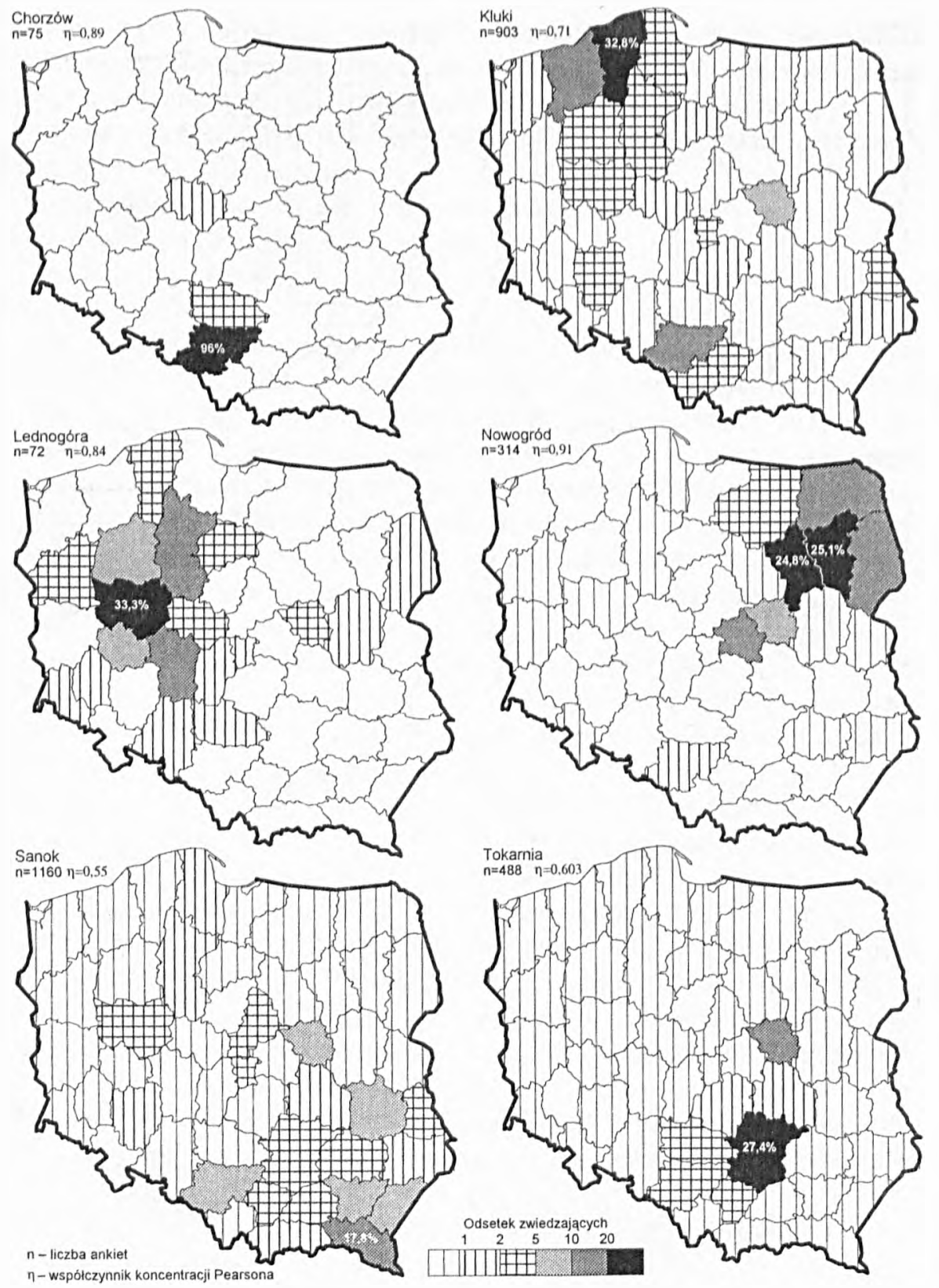

Rys. 13. Grupy zorganizowane zwiedzajace wybrane skanseny w Polsce wg województw (opracowanie własne na podstawie badań ankietowych i informacji dyrekcji muzeów)

Dessin 13. Les groupes organisés visitant les musées ethnographiques en Pologne selon les voïvodies (élaboration propre à la base des recherches d'enquêtes et des informations fournies par la direction des musées) 
publiczności muzealnej. Zdecydowanie najmniej pojawiało się w skansenie turystów z tzw. Ściany Wschodniej, Podkarpacia oraz słabiej zurbanizowanych obszarów w centrum kraju.

Zasięg oddziaływania Muzeum Wsi Słowińskiej w odniesieniu do grup zorganizowanych jest wyraźnie mniejszy niż w przypadku turystów indywidualnych (rys. 13). Niemal co trzecia wycieczka odwiedzająca tę placówkę pochodziła z województwa słupskiego, a $15 \%$ wyruszało z sąsiedniego województwa koszalińskiego. Na dwu kolejnych miejscach uplasowały się województwa: katowickie $(10,1 \%)$ i warszawskie $(5,3 \%)$.

Wyraźna dominacja regionu nadmorskiego wynika z dwóch przyczyn. Po pierwsze, przed sezonem turystycznym do skansenu trafiają niemal wyłącznie wycieczki szkolne z województwa słupskiego i terenów ościennych. Grupy z dalej położonych części kraju zwiedzają muzeum w Klukach głównie w okresie letnim (obozy i kolonie nad morzem). Po drugie, w statystykach muzealnych jako organizatorzy wakacyjnych wycieczek figuruje wiele miejscowych firm, mimo że uczestnikami tego typu imprez są urlopowicze z różnych stron Polski. Z tego powodu udział grup „słupskich” i „koszalińskich” jest zawyżony w stosunku do rzeczywistego pochodzenia zwiedzających.

Ze względu na brak porównywalnych badań w przeszłości niemożliwa jest pełna analiza ruchu turystycznego $w$ wybranych skansenach w ujęciu dynamicznym. Autor dysponował jedynie wynikami dwóch podobnych analiz: dla Wielkopolskiego Parku Etnograficznego w Lednogórze (W r z e s i ń s k a 1989) i Muzeum Budownictwa Ludowego w Sanoku (B I i n - O I b e r t 1988, tylko dla grup zorganizowanych).

W przypadku Wielkopolskiego Parku Etnograficznego w ciagu ostatnich 10 lat zasięg przestrzennego oddziaływania nie uległ jakimś poważniejszym zmianom.

A. W r z e s iń s k a (1989) nie podaje, co prawda, dokładnej analizy miejsc zamieszkania, ale pośrednio świadczy o tym choćby podobny odsetek turystów z województwa poznańskiego (Poznań - 27,2\%, Gniezno - 8,4\%, w 1997 r. odpowiednio: 32,1\% i 8,6\%). Zarówno w 1988, jak i 1997 r. większość indywidualnych zwiedzających stanowili mieszkańcy miast (odpowiednio: 81,7\% i 87,9\%).

Muzeum Budownictwa Ludowego w Sanoku już w 1987 r. charakteryzowało się krajowym zasięgiem oddziaływania (por. B I i n - O I b e r t 1988). Dominacja południowo-wschodniej Polski była jednak wtedy znacznie bardziej wyraźna (rys. 14). Blisko połowa wycieczek $(48,2 \%)$ pochodziła z województw krośnieńskiego, przemyskiego i rzeszowskiego, przy czym na samo krośnieńskie przypadała ponad $1 / 3$ grup. Z pozostałych województw jedynie katowickie i warszawskie przekroczyły granicę $5 \%$.

Zmiany przestrzennego zróżnicowania pochodzenia grup wycieczkowych w latach 1987-1997 (rys. 15) dowodzą stałego poszerzania się zasięgu oddziaływania MBL w Sanoku. Ogółem 24 województwa zanotowały wzrost udziału wśród zwiedzających skansen, w 14 nie zaobserwowano większych zmian, 


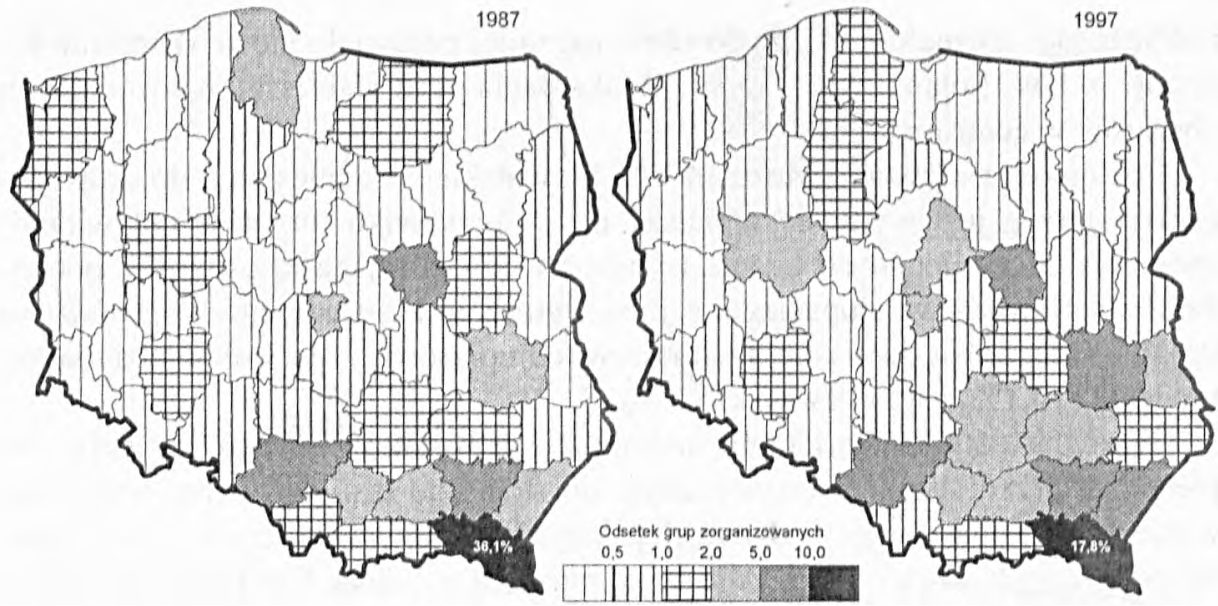

Rys. 14. Pochodzenie zorganizowanych grup zwiedzających MBL w Sanoku w 1987 i 1997 r. (opracowanie własne za D. B I i n-O I b e r 1988 i na podstawie danych dyrekcji MBL)

Dessin 14. Le origine des groupes organisés visitant le Musée de la Construction Populaire à Sanok en 1987 et 1997 (élaboration propre d'aprés D. B I i n - O I b e r t 1988 et à la base des données fournies par la direction du Musée)

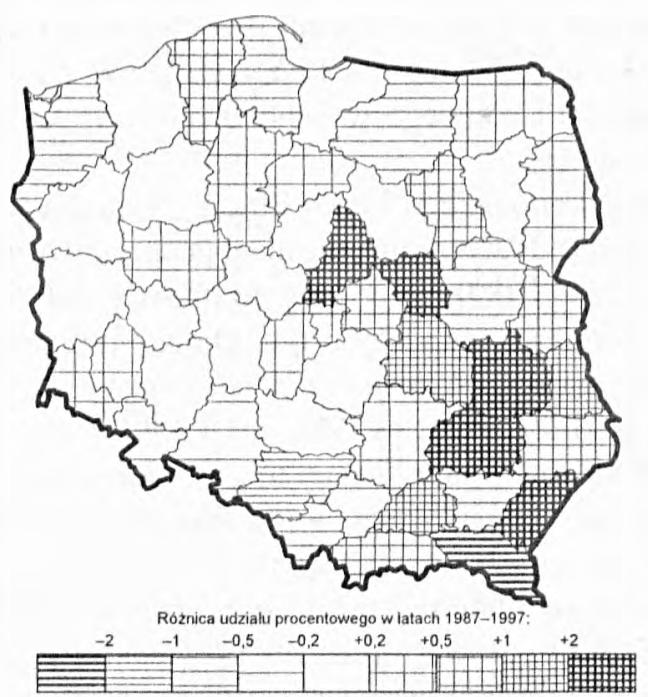

Rys. 15. Zmiany pochodzenia zorganizowanych grup zwiedzających MBL w Sanoku w latach 1987-1997 (opracowanie własne za D. B I i n-O I b e r 1988 i na podstawie danych dyrekcji MBL)

Dessin 15. Les changements de l'origine des groupes organisés visitant le Musée de la Construction Populaire à Sanok dans les années 1987-1997 (élaboration propre d'aprés D. B 1 i n - O I b e r t 1998 et à la base des données fournies par la direction du Musée) 
a spadek miał miejsce jedynie w 11 (w tym na obszarach dotkniętych powodzią w 1997 r.). Poszerzanie zasięgu oddziaływania muzeum nastąpiło przede wszystkim w wyniku spadku udziału 2-3 województw (które i tak dostarczają najwięcej zwiedzających). Skansen odwiedza coraz mniej wycieczek z najbliższego regionu (woj. krośnieńskie, rzeszowskie), wzrósł natomiast odsetek przybywających z dalej położonych województw (lubelskiego, płockiego, tarnobrzeskiego, warszawskiego, chełmskiego, radomskiego czy tarnowskiego).

\section{ZAKOŃCZENIE}

Podsumowując powyższe krótkie charakterystyki ruchu turystycznego w poszczególnych muzeach skansenowskich można sformułować kilka wniosków ogólniejszej natury.

1. Wydarzenia polityczne i społeczne mają wyraźny wpływ na zmiany frekwencji w placówkach kulturalnych, w tym także i muzeach. Liczba turystów w polskich skansenach ulegała $\mathrm{w}$ przeszłości wielu wahaniom głównie $\mathrm{z}$ powodu takich zewnętrznych, niezależnych czynników. Po gwałtownym załamaniu na początku lat dziewięćdziesiątych obecnie we wszystkich placówkach notuje się systematyczny wzrost frekwencji. W porównaniu z zachodnioeuropejskimi muzeami frekwencja w największych polskich skansenach jest jednak i tak kilkakrotnie niższa.

2. Do najważniejszych czynników wpływających na wielkość ruchu turystycznego należy zaliczyć atrakcyjność skansenu i jego położenie. Liczba zwiedzających jest tym większa, im bogatsza i bardziej zróżnicowana jest ekspozycja muzealna (wartość współczynników korelacji Pearsona zarówno dla 24 muzeów w całej Polsce, jak i sześciu analizowanych placówek oscylowała w granicach $0,5)$. Wzrostowi frekwencji sprzyja także usytuowanie placówki w popularnych regionach turystycznych (wartość współczynników korelacji Pearsona odpowiednio: 0,2 i 0,5 ). Mimo że większość odwiedzających stanowią mieszkańcy miast, mniejsze znaczenie ma lokalizacja na terenach wysoko zurbanizowanych. Nie stwierdzono natomiast istotnych zależności pomiędzy liczbą zwiedzających a czasem funkcjonowania oraz powierzchnią muzeów skansenowskich.

3. Przemiany ustrojowe przełomu lat osiemdziesiątych i dziewięćdziesiątych przyniosły także wiele jakościowych zmian frekwencji.

Wyraźnie zaznaczyły się przemiany strukturalne publiczności. Upadek turystyki socjalnej spowodował niemal całkowitą likwidację tzw. wycieczek zakładowych. Grupy zorganizowane ograniczają się praktycznie tylko do wycieczek szkolnych. Coraz większą rolę odgrywają natomiast turyści indywidualni, którzy w niektórych placówkach stanowią już ponad połowę zwiedzających. Ponieważ tendencja do stopniowej dominacji turystyki indywidualnej wydaje 
się być trwała, w najbliższym czasie można spodziewać się podobnego „odwrócenia" struktury również i w pozostałych muzeach skansenowskich.

4. Przemiany strukturalne znalazły swoje odzwierciedlenie również w zmianach sezonowości ruchu turystycznego (rozciągnięcie w czasie letniego maksimum, eliminacja jesiennego „szczytu”). Na podstawie zebranego materiału trudno jednak w tej chwili autorytatywnie stwierdzić, czy zmiany te mają charakter trwały.

5. Po roku 1990 wyraźnie zmniejszyła się liczba turystów zagranicznych z Europy Środkowo-Wschodniej, jednocześnie zwiększył się odsetek zwiedzających z krajów zachodnioeuropejskich oraz z innych kontynentów.

Cudzoziemców trafiających do polskich skansenów można podzielić na trzy podstawowe grupy:

- Niemców wysiedlonych po II wojnie światowej z tzw. Ziem Zachodnich i ich potomków, którzy przyjeżdżają do Polski przede wszystkim ze względów sentymentalnych,

- Polonię (amerykańską, kanadyjska, australijska, a także europejską) odwiedzającą rodzinę i znajomych w Polsce,

- turystów europejskich podróżujących po Polsce w celach poznawczych (głównie Niemcy, Francuzi, Włosi i Holendrzy).

Nie jest to jednak znaczący odsetek wszystkich gości muzealnych. Według szacunków pracowników skansenów obcokrajowcy w skali całego roku stanowią z reguły kilka procent zwiedzających.

6. Zasięgi oddziaływania analizowanych skansenów w odniesieniu do zwiedzających indywidualnych i grupowych wykazują duże podobieństwa. $Z$ reguły jednak miejsca zamieszkania pojedynczych turystów są bardziej rozproszone niż miejsca pochodzenia wycieczek. Jest to bez wątpienia rezultatem większej mobilności zmotoryzowanych turystów indywidualnych.

7. Miejsca pochodzenia zwiedzających badane placówki wykazują bardzo zróżnicowany stopień koncentracji (tab. IV i V, rys. 16). W syntetycznym skrócie można scharakteryzować je następująco:

- Górnośląski Park Etnograficzny w Chorzowie - zasięg lokalny - 93\% zwiedzających mieszka w I strefie odległości do $100 \mathrm{~km}$, współczynniki koncentracji wahają się w granicach $0,87-0,97$;

- Wielkopolski Park Etnograficzny w Lednogórze - zasięg regionalny - niemal $63 \%$ indywidualnych zwiedzających pochodzi z I strefy odległości, mieszka w promieniu $200 \mathrm{~km}$, a tylko 7,3\% w strefie powyżej $500 \mathrm{~km}$, wartości współczynników koncentracji kształtują się na poziomie $0,77-0,84$;

- Kurpiowski Park Etnograficzny w Nowogrodzie Łomżyńskim - zasięg ponadregionalny - 37,9\% turystów z I strefy odległości, prawie $60 \%$ zamieszkuje w odległości do $300 \mathrm{~km}$ od skansenu, a co dziesiąty musiał pokonać ponad $500 \mathrm{~km}$, współczynniki koncentracji oscylują między 0,81 a 0,91 ; 
T a b e l a IV

Koncentracja przestrzenna ruchu turystycznego w wybranych skansenach w Polsce La concentration spatiale du mouvement touristique dans les musées ethnographiques en Pologne

\begin{tabular}{|l|c|c|c|}
\hline \multirow{3}{*}{ Skansen } & \multicolumn{3}{|c|}{ Współczynnik koncentracji } \\
\cline { 2 - 4 } & zwiedzający indywidualni & grupy zorganizowane \\
\cline { 2 - 4 } & do powierzchni & do ludności & do ludności \\
\hline Chorzów & 0,967 & 0,868 & 0,892 \\
Kluki & 0,647 & 0,452 & 0,705 \\
Lednogóra & 0,824 & 0,766 & 0,838 \\
Nowogród & 0,825 & 0,809 & 0,911 \\
Sanok & 0,699 & 0,534 & 0,545 \\
Tokarnia & 0,752 & 0,564 & 0,633 \\
\hline
\end{tabular}

Ź r ó d l o: Opracowanie własne.

$\mathrm{T}$ a b e l a $\mathrm{V}$

Indywidualni zwiedzający w wybranych skansenach w Polsce wg stref odległościowych

Les visiteurs idividuels dans les musées ethnographiques en Pologne selon les zones d'éloignement

\begin{tabular}{|l|c|c|c|c|c|}
\hline \multirow{3}{*}{ Skansen } & \multicolumn{5}{|c|}{ Udzial zwiedzających (w \%) w poszczególnych strefach odległości: } \\
\cline { 2 - 6 } & $\begin{array}{c}\text { strefa I } \\
<100 \mathrm{~km}\end{array}$ & $\begin{array}{c}\text { strefa II } \\
<200 \mathrm{~km}\end{array}$ & $\begin{array}{c}\text { strefa III } \\
<300 \mathrm{~km}\end{array}$ & $\begin{array}{c}\text { strefa IV } \\
<500 \mathrm{~km}\end{array}$ & $\begin{array}{c}\text { strefa V } \\
>500 \mathrm{~km}\end{array}$ \\
\hline Chorzów & 93,06 & 94,91 & 97,22 & 97,69 & 100,00 \\
Kluki & 12,50 & 17,50 & 29,58 & 70,42 & 100,00 \\
Lednogóra & 62,74 & 75,48 & 87,58 & 92,68 & 100,00 \\
Nowogród & 37,91 & 63,73 & 76,37 & 90,10 & 100,00 \\
Sanok & 18,38 & 26,79 & 46,42 & 73,52 & 100,00 \\
Tokarnia & 33,99 & 71,43 & 78,82 & 88,67 & 100,00 \\
\hline
\end{tabular}

Uwaga: Zagranicznych zwiedzających zaliczono do strefy $>500 \mathrm{~km}$.

Ź r ó d ł o: Opracowanie wlasne na podstawie badań ankietowych w latach 1996-1997.

- Muzeum Wsi Kieleckiej - Park Etnograficzny w Tokarni - zasięg ponadregionalny - co trzeci ankietowany pochodził z I strefy, kolejne 37,4\% - z II strefy, 11,3\% zwiedzających to mieszkańcy ostatniej strefy (>500 km), współczynniki koncentracji przybierają wartości z przedziału 0,56-0,75;

- Muzeum Budownictwa Ludowego w Sanoku - zasięg krajowy - w promieniu $100 \mathrm{~km}$ mieszka zaledwie $18,4 \%$ ankietowanych, zaś w promieniu $300 \mathrm{~km}-2 / 3$ gości muzealnych, co czwarty przebył jednak więcej niż $500 \mathrm{~km}$, współczynniki koncentracji wynoszą $0,53-0,7$;

- Muzeum Wsi Słowińskiej w Klukach - zasięg krajowy/międzynarodowy w tym przypadku konieczny jest podział na zwiedzających indywidualnych 
i grupowych; pochodzenie turystów indywidualnych wskazuje na międzynarodowy zasięg skansenu ( $12 \%$ widzów z I strefy, blisko $30 \%$ badanych ze strefy powyżej $500 \mathrm{~km}$, ponad 15\% obcokrajowców, współczynniki koncentracji $0,45-0,65)$, miejsca pochodzenia wycieczek natomiast sugerują zasięg regionalny lub - po uwzględnieniu wspomnianych wcześniej zastrzeżeń w stosunku do danych wyjściowych - co najwyżej krajowy (współczynnik koncentracji 0,71 ).

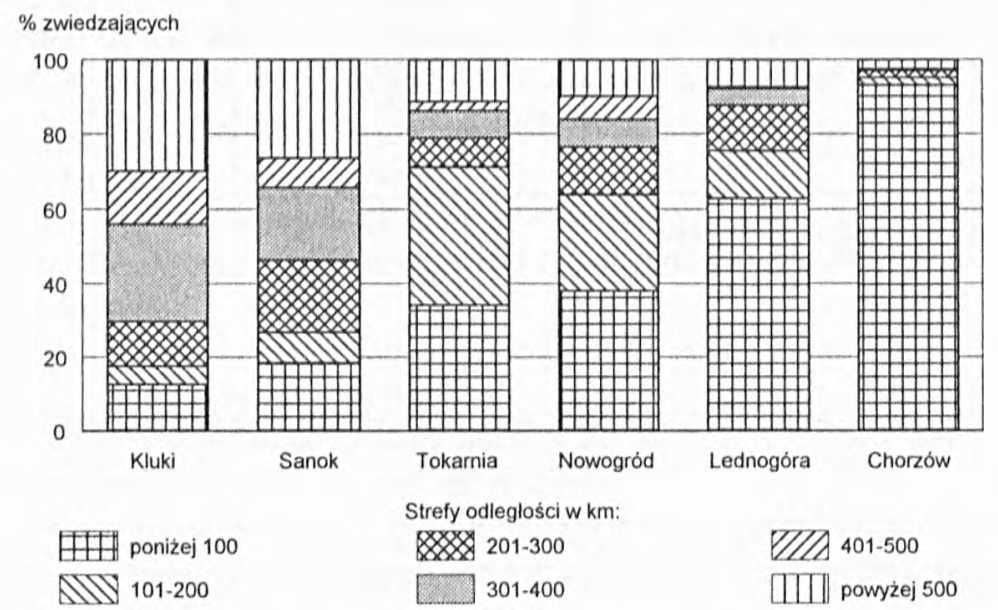

Rys. 16. Koncentracja przestrzenna zwiedzających wybrane skanseny wg stref odległości (opracowanie własne na podstawie badań ankietowych w latach 1996-1997)

Dessin 16. La concentration spatiale des visiteurs dans les musées ethnographiques selon les zoness d'éloignement

(élaboration propre a la base des recherches d'enquêtes faites dans les années 1996-1997)

8. Ze względu na brak porównywalnych badań w przeszłości niemożliwa okazała się pełna analiza ruchu turystycznego w ujęciu dynamicznym. Wyrywkowe dane wskazują, że zasięgi oddziaływania skansenów mogą ulegać istotnym zmianom (wzrastać). Jest to jednak proces powolny i długotrwały.

\section{PIŚMIENNICTWO}

B I i n - O I b e r t D., 1988, Dziatalność oświatowa Muzeum Budownictwa Ludowego w Sano$k u$, ,Materiały Muzeum Budownictwa Ludowego", nr 30.

C z a j k ow s k i J., 1981, Raport o stanie muzealnictwa skansenowskiego w Polsce, „Acta Scansenologica", t. 2. 
D u d e k P., 1995, Marketing i promocja rekreacji oraz wypoczynku świqtecznego w województwie katowickim, [w:] Marketing i promocja turystyki na Górnym Ślqsku, J. Siekierski, J. Ślusarczyk (red.), Górskie Towarzystwo Naukowe, Katowice.

G e r l a c h - Jó s e w i c z A., 1975, Wybrane problemy przepustowości turystycznej muzeów, „Zeszyty Naukowe Instytutu Turystyki", Warszawa.

K a c z m a r e k S., L i s z e w s k i S., 1989, Funkcja turystyczna Kartuz, „Acta Universitatis Lodziensis", Turyzm, nr 5.

R o d a c k a M., 1997, Wykorzystanie turystyczne dziedzictwa kulturowego Kaszubów, „Turyzm” t. 7, z. 2.

S p is s A., 1985, Muzea etnograficzne na wolnym powietrzu w Europie, Biblioteka Muzealnictwa i Ochrony Zabytków, Studia i Materialy, t. II., ODZ, Warszawa.

S t a s i a k A., 1996, Muzea na wolnym powietrzu w Polsce i możliwości ich wykorzystania dla celów turystycznych, Turyzm, t. 6, z. 2.

S t a s i a k A., 1998a, Ruch turystyczny $w$ Wielkopolskim Parku Etnograficznym w Dziekanowicach, Studia Lednickie, t. V, Muzeum Pierwszych Piastów na Lednicy, Lednica - Poznań.

S t a s i a k A., 1998b, Funkcja turystyczna polskich skansenów, [w:] Wieś wspólczesna. Kontynuacja i zmiana, Materialy z konferencji "Wartości kultury tradycyjnej a wieś wspótczesna”, Łódż 14-15 marca 1997 r., „Łódzkie Studia Etnograficzne”, t. 37.

S t a s i a k A., 1999, Ruch turystyczny w Muzeum Budownictwa Ludowego w Sanoku, [w:] Materialy z Międzynarodowej Konferencji Muzealnej „Ochrona tradycyjnego budownictwa. Osiqgnięcia, problemy i możliwości wspóldziatania w Karpatach polskich, stowackich i ukrainskich", Sanok 7-10 października 1998 r. (w druku).

W r z e s i ń s k a A., 1989, Wyniki ankiety przeprowadzonej w 1988 roku na terenie Wielkopolskiego Parku Etnograficznego w Dziekanowicach, maszynopis w archiwum Muzeum Pierwszych Piastów na Lednicy.

Z i e m b i ń s k i J., 1994, Muzea w okresie przetomu. Próba analizy historyczno-socjologicznej, ,,Materiały Państwowego Muzeum Zamkowego w Pszczynie”, t. VIII.

Mgr Andrzej Stasiak

Studium Doktoranckie Geografii

Uniwersytet Lódzki

al. Kopcińskiego 31

90-142 Łódź

\section{RÉSUMÉ}

L'article constitue l'addition d'une partie des recherches faites par l'auteur dans les années 1996-1997 dans six musées ethnographiques (musées à: Chorzów, Kluki, Lednogóra (Dziekanowice), Nowogród Łomżyński, Sanok, Tokarnia). Au total les recherches d'enquête ont embrassé 1500 visiteurs des musées âgés de plus de 18 ans (tabl. I), et les questions se rapportaient en principe à toute une famille ou à un groupe (réellement les recherches ont embrassé trois ou quatre fois plus de personnes).

Les conclusions déduites de ces recherches sont comme suit:

1. L’influence des événements politiques et sociaux en Pologne sur le nombre de visiteurs dans les musées était bien sensible. Eu égard aux oscillations de la frequence dans les musées ethnographiques polonais, on peut distinguer nettement cinq périodes (desssin 2): 
- Ies années soixante-dix: l'accroissment systématique du nombre de visiteurs (p.ex. au Musée des Constructions Populaires à Sanok il a doublé en atteignant 95000 personnes en 1978);

- les années 1980-1982: l'effondrement violent de la fréquence qu'a entraîné la situation sociale et politique du pays (crise économique, état de guerre);

- les années 1983-1989: l'accoroissement suivant de la fréquence (le musée à Sanok est visite pour la deuxiéme fois par 95000 personnes, les autres musées notent la fréquence maximale dans leur histoire;

- les années 1990-1992: la nouvelle baisse violente de la fréquence (méme de 50\%) qu'a entraînée la transformation du régime et les changements sociaux et économiques en Pologne aprés 1989;

- les années 1993-1997: la „reconstruction” systematigue du niveau de fréquence d'avant 1990, dans tous les musées ethnographiques la tendance de hausse se fait remarquer.

2. Les attraits du musee et sa situation décident de la grandeur du mouvement touristique. Il est plus grand dans les régions touristiques, moindre dans les musees localisés sur les terrains hautement urbanisés. On n'a pas constaté la dépendance entre le nombre de visiteurs et le temps de fonctionnement ainsi que la superficie des musées ethnographiques.

3. Aprés 1990 se sont manifestés les changements structuraux du public. La chute du tourisme social a presque totalement anéanti les excursions organisées par les établissementes. A présent pratiquement les groupes organisés sont composés d'écoliers. Les touristes individuels jouvent le rôle de plus en plus grand, dans certains musées ils constituent plus que la moitié de visiteurs (le détournement de la structure des visiteurs a lieu).

4. Les changement structuraux se reflétent aussi dans ceux du caractére saisonnier du mouvement touristique (l'allongement dans le temps du maximum d'été, l'élimination du sommet d'automne). Cependant il est impossible de dire si ces changements sont durables.

5. Le nombre de touristes étrangers venant des pays de l'Europe Centrale et Orientale a baissé tandis que le pourcentage de ceux arrivant de l'Ouest de l'Europe et des autres continents a augmenté.

Ce sont avant tout:

- les Allemands expulsés des terres dites d'Ouest et leurs descendants qui visitent notre pays eu égard aux sentiments gardés dans les familles;

- les Polonais vivant à l'étranger (en Ameérique, en Australie, en Europe) faisant visite aux personnes avec lesquelles ils ont un lien de parenté;

- les touristes dont le voyage en Pologne a un but instructif (avant tout - Allemands, Français, Italiens, Hollandais). La participation des étrangers vue en perspective de toute l'année est minime (quelque pourcent seulement).

6. Les lieux de l'origine territoriale des visiteurs dans les musées démontrent le degré de concentration trés différencie (Tabl. IV et V, Dessin 16). Dans un raccourci synthétique il est comme suit:

- Le Parc Ethnographique de Haute Silésie à Chorzów - étendue locale,

- Le Parc Ethnographique de Wielkopolska à Lednogóra - étendue régionale,

- Le Parc Ethnographique de Kurpie à Nowogród Łomżyński et le Musée de la Campagne à Kielce - étendue surrégionale,

- Le Parc Ethnographique à Tokarnia - étendue surrégionale,

- Le Musée de la Construction Populaire à Sanok - étendue nationale,

- Le Musée de la Campagne Slovine à Kluki - étendue nationale (touristes venant en groupes) - étendue internationale (touristes individuels). 


\section{SUMMARY}

The article is the round-up of a part of research carried out by the author in the period of 1996-1997 in six Polish ethnographical museums (in Chorzów, Kluki, Lednogóra, Dziekanowice, Nowogród Łomżyński, Sanok and Tokarnia). All in all, nearly 1,5 thousand museum visitors above 18 years of age took part in the survey (Table I), and their answers mostly referred to the whole family or group (in fact three or four times more people took part in the survey).

Here are the most important conclusions from the survey:

1. Political and social events in Poland clearly affected the number of tourists in the museums. Because of the differences in the numbers of tourists one can isolate five distinctive periods (Fig. 2):

- the 1970's - a gradual increase in the number of visitors (e.g. in MFA in Sanok, within a few years the numbers doubled, reaching 95 thousand people in 1978);

-1980-1982 - a drastic fall in the numbers of visitors due to the unstable social and political situation in Poland (economic crisis, martial war);

- 1983-1989 - the next period of increase (MFA in Sanok the numbers again reached 95 thousand, many other museums observe the highest numbers of visitors ever);

- 1990-1992 - another rapid decrease in the numbers of visitors (even by $50 \%$ ), as a result of the political transformation and socioeconomic changes in Poland after 1989;

- 1993-1997 - gradually working towards the numbers of visitors noted before 1990, in all the ethnographical museums one can observe an increase in the numbers.

2. Among the most important factors affecting the intensity of the tourist traffic in an ethnographical museum are its attractiveness and localization (in the popular tourist regions; localization in highly urbanized areas is less significant). There are, however, no significant correlations between the number of the visitors and the operational time and the area of the ethnographical museums.

3. After 1990 one can observe clear structural changes in the audience. The downfall of the social tourism resulted in an almost complete disappearance of trips organized in the places of employment. Presently organized groups are practically only school excursions. Individual tourists are becoming more and more important, in some museums they constitute over half of the visitors (so called 'converted structure of the visiting people').

4. Structural changes were also reflected in the changes in the seasonality of the tourist traffic (the extension of the summer maximum, elimination of the autumn peak). It is, however, difficult to conclude at the moment whether these changes are permanent.

5. One can also observe a noticeable decrease in the number of foreign tourists from Central and Eastern Europe, and at the same time an increase in the number of tourists from Western Europe and other continents. They are mostly:

- Germans expatriated after World War II from so called Western lands, and their descendants, who come to Poland mainly for sentimental reasons;

- Polonia (Polish emigration in America, Australia and Europe) visiting their families in Poland:

- European tourists traveling over Poland for solely tourist reasons (mainly Germans, the French, Italians and the Dutch).

Annually, however, foreigners constitute only a few percent of the museum visitors.

6. The places of origin of the museum visitors show a strongly varied concentration (Tables IV and V, Fig. 16). Very briefly they are as follows:

- Upper-Silesian Ethnographic Park in Chorzów - local range,

- Ethnographic Park of Wielkopolska in Lednogóra - regional range,

- Ethnographic Park of Kurpie in Nowogród Lomżyński and the Museum of the Kielecka Country - The Ethnographic Park in Tokarnia - supraregional range, 
- The Museum of Folk Architecture in Sanok - national range,

- The Museum of Słowińska Country in Kluki - national range (group tourists) or even international range (individual tourists).

Translated by Ewa Mossakowska 